\title{
Geology and Geochemistry of Sediments from Lewumeji and Idogun Wells, Eastern Dahomey Basin Southwestern Nigeria
}

\author{
Adeigbe, O.C* $\quad$ Oyekola, C.B \\ Department of Geology, University of Ibadan, Nigeria \\ Corresponding author: Dr O.C. Adeigbe, Department of Geology, University of Ibadan, Nigeria
}

\begin{abstract}
Selected composited samples from Lewumeji (0-111m) and Idogun (0- 54m) Abeokuta Group, Eastern Dahomey Basin, were subjected to detailed lithologic and geochemical studies. The studies aimed at determining the lithological sequence, paleoenvironments of deposition, tectonic settings, provenance, weathering history and the classification of sediments. The core samples were subjected to lithological description and geochemical analysis were done following standard procedure through the use of Inductively Coupled Plasma Mass Spectrometry (ICPMS) and Inductively Coupled Plasma Optical Emission Spectrometry (ICP-OES) through lithium metaborate fusion method.The lithologies from both wells consist of reddish to brown colour, rounded to sub rounded sandstone, brownish clay, and dark grey shale denoting possibly fluvial, brackish, lagoonal and marine environments. The sandstone revealed dominance of quartz which were classified as quartz arenites to sublitharenite and subarkoses, this suggests a recycled orogen source for the sandstones. Shale in the study area shows patches of $\mathrm{CaCO}_{3}$ indicating the presence of biogenic materials. And the reddish brown colouration of clay suggests ferruginization. The geochemistry revealed low values for $\mathrm{K}_{2} \mathrm{O} / \mathrm{Al}_{2} \mathrm{O}_{3}$ ratio coupled with high average values of Plagioclase Index of Alteration $(81.64 \%$ and $73.80 \%)$, Chemical Index of Alteration $(79.22 \%$ and $71.52 \%)$ and Chemical Index of Weathering $(82.41 \%$ and $75.03 \%)$ for Idogun and Lewumeji wells respectively. This values indicate intense weathering condition. The plots of $\log \left(\mathrm{Fe}_{2} \mathrm{O}_{3} / \mathrm{K}_{2} \mathrm{O}\right)$ against $\log \left(\mathrm{SiO}_{2} / \mathrm{Al}_{2} \mathrm{O}_{3}\right)$ revealed sediments dominated by $\mathrm{Fe}$ - sand and $\mathrm{Fe}$ - shale. Also, $\mathrm{Al}_{2} \mathrm{O}_{3}-\left(\mathrm{K}_{2} \mathrm{O}+\mathrm{CaO}+\mathrm{MgO}\right)-\left(\mathrm{Fe}_{2} \mathrm{O}_{3}+\mathrm{MgO}\right)$, ( $\mathrm{AKF}$ ) ternary plots reveals that the sediments are derived from continental environment. The $\mathrm{Log}\left(\mathrm{K}_{2} \mathrm{O} / \mathrm{Na}_{2} \mathrm{O}\right)$ against $\mathrm{SiO}_{2}$ and the discriminant function plots indicate sediments deposited within the passive margin. Also, the Trace elements ternary plots of Th-Sc-Zr/10 and Th-Co-Zr/10 reveal deposition within Continental Island Arc and Passive Margin. The discriminant function plots characterized the sediments as Mafic Igneous rock and quartoze sedimentary provenances with minor input from Intermediate and felsic igneous provenances. The chondrite normalized REE plots show enrichment of Light REE over Heavy REE in the study area with negative Europium and Cerium anomalies greater than 1 . This indicated an oxidising and a shallow marine environments. The REE pattern is similar to those for the Upper Continental Crust sediments (UCC). Conclusively, the study shows that the sediments in the study area have multiple provenances subjected to high weathering conditions and were deposited within an oxidizing and continental to shallow marine settings.
\end{abstract}

Keywords: Dahomey Basin, lithostratigraphy, paleoenvironment, Provenance, Tectonic setting.

DOI: $10.7176 / \mathrm{JEES} / 10-5-03$

Publication date:May $31^{\text {st }} 2020$

\section{Introduction}

The Dahomey Basin is one of the sedimentary basins on the continental margin, it is a pre-cratonic basin that was developed during the initiation of rifting associated with the opening of Gulf of Guinea in early Creataceous to Late Jurassic (Burke et al., 1971; Klemme, 1975; Whiteman, 1982; Kingston et al., 1983). The Eastern half of the basin occurs within the Nigerian territory. The northern part of the basin in Nigeria is the exposure of the Abeokuta group which is unconformably overlying the basement. The basin consists of Cretaceous-Tertiary sequence, which outcrops in an arcuate belt roughly parallel to the ancient coastline and it is characterized by block and transform faulting superimposed across an extensive Paleozoic basin during the breakup of African, North American and South American paleo-continents. The states within the Eastern Dahomey basin in the Nigerian sector include Lagos, Ogun, Ondo and Benin (Elueze and Nton, 2005).

This study describes the geochemical composition of Sandstones, Shales and clay of Lewumeji $(0-111 \mathrm{~m})$ and Idogun $(0-54 \mathrm{~m})$ well, Eastern Dahomey Basin Southwestern Nigeria (Fig 1). The geochemical studies of sedimentary basins are useful indicators of depositional environment, facies and diagenetic changes (Lewis and Banderia, 1981). The geochemical composition of terrigenous sedimentary rocks is a function of the complex interplay of various variables, thereby providing an insight into tectonic settings, provenance, weathering history and transportation history (Bhatia, 1983). Several authors have carried out considerable and intensive researches to characterize and deduce the various lithology, paleoenvironment, provenance, tectonic setting of ancient and recent sediments (Bhatia, 1983; Bhatia and Crook, 1986; Roser and Korsch, 1986, Boboye et al., 2018). The major, trace and rare earth elements are of great importance in provenance and tectonic studies because of their variable signatures during sedimentary processes. 
This research therefore aimed at integrating lithology and geochemistry to classifying the sediment and also to deduce the depositional environment, Provenance, tectonic settings, weathering history and transportation history that prevails during sediment deposition.

\section{Location of the study area}

The studied wells are situated between latitudes $06^{0} 30^{\prime} 0^{\prime \prime} \mathrm{N}-06^{0} 37^{\prime} 0^{\prime \prime} \mathrm{N}$ and longitude $04^{0} 45^{\prime} 0^{\prime \prime} \mathrm{E}-05^{\circ} 00^{\prime} 0^{\prime \prime} \mathrm{E}$. and lie within the Abeokuta group of the Eastern Dahomey Basin (Fig.1 and Fig. 2)

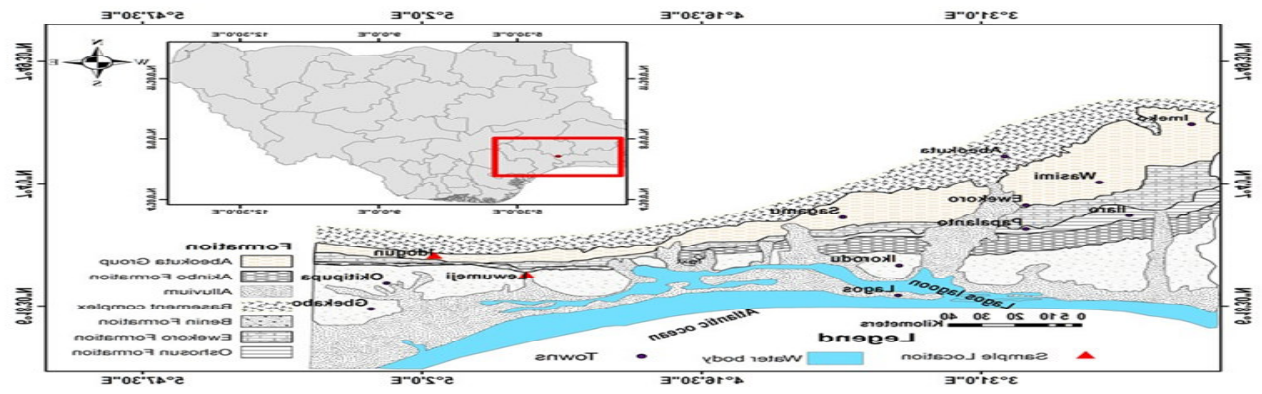

Figure 1: Map of Dahomey Basin showing the Study well (modified after Biliman, 1992)

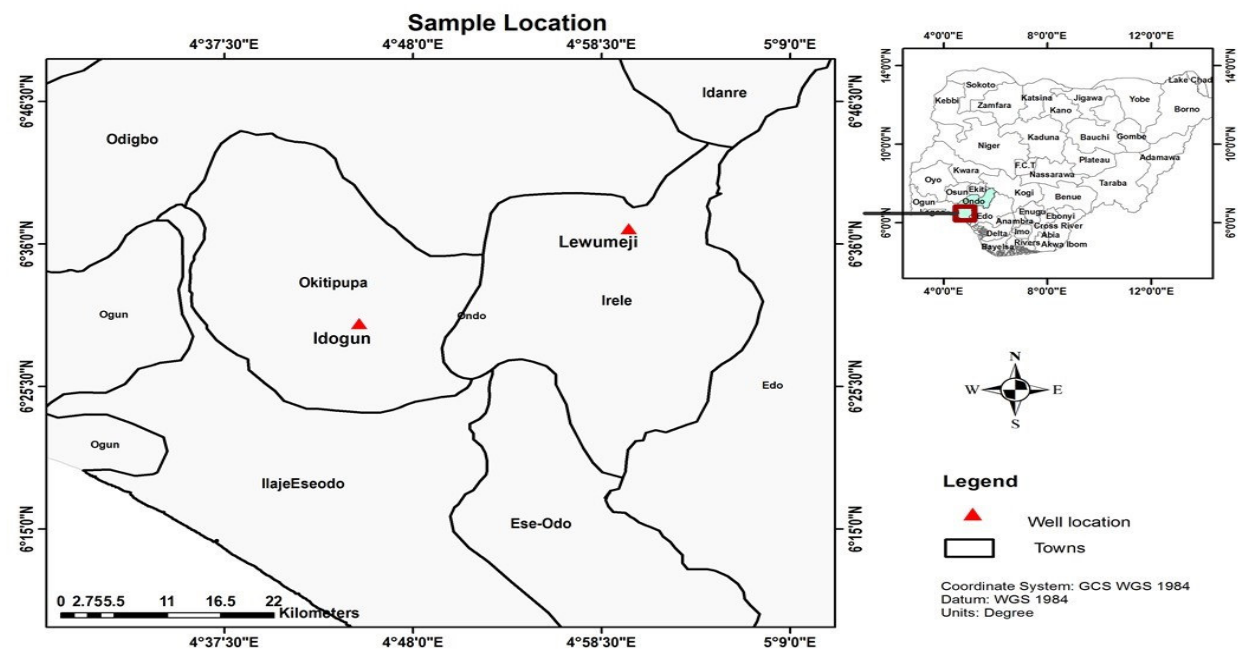

Figure 2: Location map of the exploration wells for this Study, Eastern Dahomey basin, Southwestern Nigeria.

(Inset map illustrates the position of Dahomey basin in Nigeria)

\section{Materials and Methods}

The core samples used for this study were collected from the Bitumen project base in Ore, Ondo State, Nigeria. A total of seven (7) composited samples of sandstone and shale from the Lewumeji well and five (5) composited sample of Shale, sandstone and clay from Idogun well were used for the geochemical studies. Detailed lithologic description were carried out on the core samples provided following the standard method of describing samples by using microscope hand lens, dilute $\mathrm{HCl}$ and physical examination. The description was based on their texture, Fissility, colour, and fossil content in term of plant remains and fossil fragment. Then the samples were pulverized separately using porcelain mortar and pestle at the Geochemistry Laboratory, University of Ibadan.10g of each measured samples were placed in an air tight and well labelled white cellophane bag and send for subsequent geochemical analysis at the Acme Analytical laboratory limited, Vancouver, Canada. The Inductively Coupled Plasma Optical Electron Spectrometry (ICP-OES) and Inductively Coupled Plasma Mass Spectrometry (ICP-MS) through Lithium Metaborate fusion method was used for determination of major, trace and rare earth elements. The analysed samples produce major (11), trace elements (33) and Rare Erarth Elements (14). Also, Loss on ignition (LOI) was determined for the samples through appropriate method. The detection limit for all the major element oxides is $0.01 \%$. The only exceptions are $\mathrm{Fe}_{2} \mathrm{O}_{3}$ and $\mathrm{Cr}_{2} \mathrm{O}_{3}$ which have a detection limit of $0.04 \%$ and $0.002 \%$ respectively.

\subsection{Data Interpretation and statistical Analysis}

Geological and statistical methods were used to treat the geochemical data. The statistical treatment include both univariate and multivariate statistical analysis using SPSS -17.0 software (statistical package for social science) and Microsoft excel was also used with the aim to determine the interrelationship between elements. Petrographs 
was use for tenary plottings. Plots and comparative tables were produced to aid visual identification trends in term of data variation. Correlation coefficients were developed to measure the strength of linear relationships between elemental abundance variables on a scale of -1 (perfect inverse relationship) through 0 (no relation) to +1 (perfect sympathic relation).

\section{Results and Discussion}

\subsection{Lithostratigraphic Description of the wells}

The description of the facie units are presented below while the litholog is described based on colour, texture and depth (Fig. 3 and Fig.4)

Lewumeji well : [Litho unit $1(0-9 \mathrm{~m})]$

This unit is on the topmost layer. The sandstone is reddish brown at the upper part of the unit then a light brown at the base of the layer. It has a fine to medium size grains. The unit is $15 \mathrm{~m}$ thick and was deposited in a fluvialtile environment.

\section{Litho unit $2(9-111 m)$}

This unit is $102 \mathrm{~m}$ thick. It is composed of shally, dark to grayish, fissile to non- fissile, carbonaceous shale.

Idogun well [Litho unit $1(0-9 \mathrm{~m})]$

This units is $9 \mathrm{~m}$ thick, it is reddish brown, non- carbonaceous clay. This litho unit portrays a mixed depositional environment in which there is strong influence of fluvial on lagoonal environment.

Litho unit $2(9-15 m)$

This interval is composed of fine to medium grain sandstone with an evidence of shelly whitish material in some horizons. It is $6 \mathrm{~m}$ thick and reddish brown to brown in colour. The sediment was deposited in a fluvial environment. Litho unit $3(15-24 m)$

This unit which is about $9 \mathrm{~m}$ thick is shally, dark grey in colour, non- fissile and could have been deposited in a marine environment.

Litho unit $4(24-42 m)$

This unit is made up of grey coloured sandstone. Fine to medium grained which suggest deposition in a fluvialtile environment.

\section{Lithounit 5 (42 -54m)}

This interval consists of a dark to greyish non- fissile shale. It is carbonaceous. The units is about $9 \mathrm{~m}$ thick and the high occurrence of dinoflagellates cysts like Senegalinium sp suggests position in a marine setting. 4.2 Geochemistry

\section{Major element geochemistry}

Major elemental oxide is a reflection of the duration and intensity of variables such as provenance, weathering, transportation and diagenesis (Boboye et al., 2018). This can also be of use when contemplating certain trends in the general composition of the sedimentary rocks and to decipher the weathering profile of the rock (Nesbitt and Young 1982; Fedo et al., 1995). Observations from the major element result from the well shows high

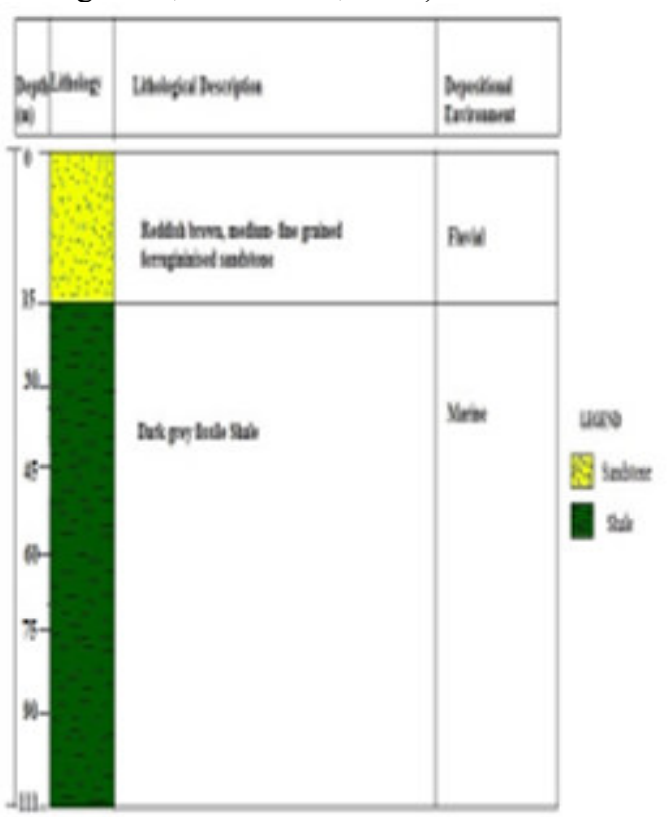

Figure 3: Litholog of the studied interval of Idogun well, Dahomey Basin, Nigeria

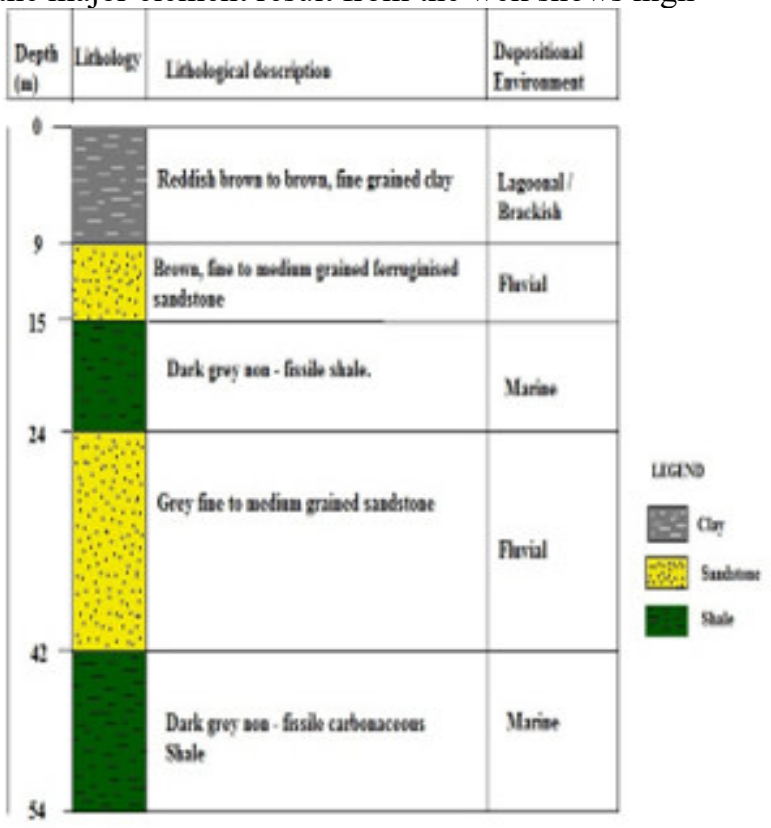

Figure 4: Litholog of the studied interval of Lewumeji well, Dahomey Basin, Nigeria 
abundance and large variations of $\mathrm{SiO}_{2}$ ranging from $90.72 \%-36.39 \%$ with an average value of $50.18 \%$ for the lewumeji well and $99.14 \%-42.48 \%$ with an average of $70.81 \%$ for Idogun well. This average value islower in Lewumeji and higher in Idogun well than the value for the upper continental crust (UCC), $\mathrm{Al}_{2} \mathrm{O}_{3}$ is moderately high ranging from 3.7\% - 19.8\% (average: 14.09\%) and 1.66\% $-19.72 \%$ (average: $12.7 \%$ ) for Lewumeji and Idogun well respectively, the concentration of Aluminosilicate is a good measure of detrital flux (Nagarajan, et. al., 2007) and the mean high concentrations of $\mathrm{Al}_{2} \mathrm{O}_{3}$ may indicate a high Kaolinite/illite ratio within the study area (Besly and Clearl, 1997). Concentration of $\mathrm{Fe}_{2} \mathrm{O}_{3}$ in Idogun well and lewumeji varies from 8.6\% - 1.04\% (average: 5.21\%) and 2.41\% -9.55\% (average: 5.9\%) This appreciable value of $\mathrm{Fe}_{2} \mathrm{O}_{3}$ can be from the source rock, indicating that the source rock may contain an appreciable biotite and hornblende, it can also indicate oxidation condition (Bassey and Eminue 2014). $\mathrm{CaO}$ ranges between $0.07 \%-11.79 \%$ (average: $4.3 \%$ ) in Idogun and $0.12 \%$ - $15.11 \%$ (average: $5.6 \%$ ). Also the $\mathrm{MgO}$ concentration is relatively low in Lewumeji it ranges between $0.05 \%-$ $5.19 \%$ (average: $3.39 \%$ ) and Idogun ranges between $0.03 \%-0.7 \%$ (average: 0.45 ). Which implies that the sediments contain minute amount of ferromagnesian minerals such as mica, hornblende and haematite. The low value of $\mathrm{MgO}$ and $\mathrm{CaO}$ contents indicates associated carbonate or dolomitization. However the concentration of $\mathrm{TiO}_{2}, \mathrm{Na}_{2} \mathrm{O}, \mathrm{K}_{2} \mathrm{O}, \mathrm{P}_{2} \mathrm{O}_{5}, \mathrm{MnO}$ and $\mathrm{Cr}_{2} \mathrm{O}_{5}$ are relatively low. The low $\mathrm{K}_{2} \mathrm{O}$ content indicated low amount of illite or $\mathrm{K}$-feldspar present in the sediment (Akpokodje et al., 1991) and the low phosphate $\left(\mathrm{P}_{2} \mathrm{O}_{5}\right)$ content could be attributed to lower amount of accessory phases such as apatile and monazite. The summary of major element of Lewumeji and Idogun wells is given in Table 1 and 2 respectively.

The Silica-Alumina ratio $\left(\mathrm{SiO}_{2} / \mathrm{Al}_{2} \mathrm{O}_{3}\right)$ of the studied shale sample is shown in table 3 . According to Le Maitre, (1976) $\mathrm{The} \mathrm{SiO}_{2} / \mathrm{Al}_{2} \mathrm{O}_{3}$ ratio is about 3 in basic rocks (basalts and Gabbros) and it is around 5 in the acidic end member (granites and rhyolites) Ratio more than 5 or 6 in sedimentary rocks provided evidence of sedimentary maturation (Roser et al., 1996). The $\mathrm{SiO}_{2} / \mathrm{Al}_{2} \mathrm{O}_{3}$ ratio for Lewumeji and Idogun shale samples varies between 2.95 -3.23 (average: 3.09) and $2.24-3.03$ (average: 2.24) respectively which is within the range of a basic rock. Sandstone in both wells has a significantly high value of 24.26 for Lewumeji and 11.16 - 54.71 (average: 33.93 ) for Idogun wells, indicating a high mature sediment. Which is comparable to the value of 30 reported in the modern sediment (Valloni and Maynard, 1981; McLennan et al., 1990) that interpreted as highly mature sediments. The Potassium - Alumina ratio $\left(\mathrm{K}_{2} \mathrm{O} / \mathrm{Al}_{2} \mathrm{O}_{3}\right)$ is an index of mudrock composition which can be used as an indicator of original composition of ancient sediments (Popoola et. al., 2014). The $\mathrm{K}_{2} \mathrm{O} / \mathrm{Al}_{2} \mathrm{O}_{3}$ has different ratios for clay minerals and feldspar which ranges between 0.0 to 0.3 and 0.3 to 0.9 respectively, The very low value of $\mathrm{K}_{2} \mathrm{O} / \mathrm{Al}_{2} \mathrm{O}_{3}$ of the study areas varies from 0.02 to 0.10 for lewumeji and $0.04-0.07$ for Idogun sediments generally indicating the preponderance of clay minerals over the K-bearing minerals such as K-feldspar and micas. The concentration of $\mathrm{TiO}_{2}$ increased with $\mathrm{Al}_{2} \mathrm{O}_{3}$, indicating that $\mathrm{TiO}_{2}$ is associated with Phyllosilicate especially with Illite (Dabard, 1990). The concentration of $\mathrm{Fe}_{2} \mathrm{O}_{3}$ and $\mathrm{TiO}_{2}$ (Pearse et al., 1999) indicate the presence of irontitanium minirals (haematite, anatase and rutiles). The ratios of $\mathrm{TiO}_{2} / \mathrm{Al}_{2} \mathrm{O}_{3}$ in Lewumeji and Idogun well $(0.05$ $0.10,0.04-0.16)$ and $\mathrm{Na}_{2} \mathrm{O} / \mathrm{K}_{2} \mathrm{O}(0.06-0.10,0.04-0.10)$ respectively suggests that the sediments are highly chemically mature (Jenner et al., 1981). Also, the relative high $\mathrm{K}_{2} \mathrm{O} / \mathrm{Na}_{2} \mathrm{O}$ ratios $(8.00-15.00)$ are attributed to the relatively common presence of K-bearing minerals such as K-feldspar, Illite and some micas (Pettijohn et al., 1963, Kalsbeek et al., 2008; Nath et al., 2000; Zhang, 2004; Osae et al., 2006). The $\mathrm{Al}_{2} \mathrm{O}_{3} / \mathrm{TiO}_{2}$ ratio are essentially used to infer the source rock composition of most clastic rocks this is because $\mathrm{Al}_{2} \mathrm{O}_{3} / \mathrm{TiO}_{2}$ ratio increases from 3 to 8 for mafic Igneous rock $\left(\mathrm{SiO}_{2}-45.52 \%\right), 8$ to 21 for intermediate rocks $\left(\mathrm{SiO}_{2}=53 \%-66 \%\right)$ and 21 to 70 for felsic rocks $\left(\mathrm{SiO}_{2}=66 \%-76 \%\right)$ (Hayashi et al., 1997). Therefore, the $\mathrm{Al}_{2} \mathrm{O}_{3} / \mathrm{TiO}_{2}$ ratio of the sediment ranges from $9.84-21.31$ (mean $=18.16$ ) for Lewumeji and $6.14-20.93(13.53)$ suggesting that they were possibly derived from a mafic to intermediate Igneous source.

The loss on ignition (LOI) for Lewumeji and Idogun sandstone ranges between $2.4-4.1 \%$, shales from the study wells ranges between $16.90-25.5 \%$, and clay is $9.7 \%$. The LOI for shale is high, indicating that the shale has a higher potential for carbonaceous compounds.

\subsubsection{Classification of sediments}

The standard plot of Herron (1988) using $\mathrm{Log}\left(\mathrm{Fe}_{2} \mathrm{O}_{3} / \mathrm{K}_{2} \mathrm{O}\right)$ against $\mathrm{Log}\left(\mathrm{SiO}_{2} / \mathrm{Al}_{2} \mathrm{O}_{3}\right)$ was employed to classify the sediments of the study area. From the plot (Fig.5), the shale and the clay samples from Idogun and lewumeji well dominantly falls within the Iron shale (Fe-shale) field and the sandstone from the study well falls within the Iron sand ( $\mathrm{Fe}$ - sand) compartment which is an indication of ferruginization. The sediments that fall within the Iron - sand ( $\mathrm{Fe}$-sand) field further suggest an incursion of fluvial current and this is consistent with the presence of the brownish sandstone and clay observed from the lithological description. 
Table 1: Values (Wt. \%) of Major elements of the sandstone and shale in Lewumeji well

\begin{tabular}{|c|c|c|c|c|c|c|c|c|c|c|}
\hline $\begin{array}{c}\text { Sample no } \\
\text { Major oxides }\end{array}$ & A1 & A2 & A3 & A4 & A5 & A6 & A7 & Range & Average & Median \\
\hline $\mathrm{SiO}_{2}$ & 90.72 & 41.76 & 36.39 & 45.32 & 45.09 & 45.97 & 46.04 & $36.39-90.72$ & 50.18 & 63.55 \\
\hline $\mathrm{Al}_{2} \mathrm{O}_{3}$ & 3.74 & 14.13 & 11.97 & 14 & 15.52 & 19.82 & 19.5 & $3.74-19.82$ & 14.09 & 23.56 \\
\hline $\mathrm{Fe}_{2} \mathrm{O}_{3}$ & 2.41 & 9.55 & 4.26 & 6.94 & 5.56 & 6.35 & 6.82 & $2.41-6.94$ & 5.66 & 7.14 \\
\hline MgO & 0.05 & 2.92 & 4.63 & 5.19 & 4.89 & 3.18 & 2.9 & $0.05-5.19$ & 3.39 & 2.27 \\
\hline $\mathrm{CaO}$ & 0.12 & 9.18 & 15.11 & 5.85 & 4.76 & 2.11 & 2.53 & $0.12-15.11$ & 5.66 & 14.99 \\
\hline $\mathrm{Na}_{2} \mathrm{O}$ & 0.01 & 0.05 & 0.07 & 0.1 & 0.12 & 0.13 & 0.15 & $0.01-0.15$ & 0.09 & 0.14 \\
\hline $\mathrm{K}_{2} \mathrm{O}$ & 0.08 & 0.8 & 0.86 & 1.5 & 1.11 & 1.32 & 1.43 & $0.08-1.5$ & 1.01 & 1.42 \\
\hline $\mathrm{TiO}_{2}$ & 0.38 & 0.74 & 0.66 & 0.8 & 0.75 & 0.93 & 0.98 & $0.38-0.98$ & 0.74 & 0.6 \\
\hline $\mathrm{P}_{2} \mathrm{O}_{5}$ & 0.03 & 0.18 & 0.24 & 0.46 & 0.24 & 0.09 & 0.09 & $0.03-0.46$ & 0.19 & 0.21 \\
\hline MnO & $<0.01$ & 0.19 & 0.11 & 0.04 & 0.05 & 0.03 & 0.03 & $<0.01-0.19$ & 0.06 & 0.19 \\
\hline $\mathrm{Cr}_{2} \mathrm{O}_{3}$ & 0.005 & 0.017 & 0.015 & 0.021 & 0.022 & 0.027 & 0.028 & $0.005-0.028$ & 0.01 & 0.023 \\
\hline LOI & 2.4 & 20.3 & 25.5 & 19.5 & 21.7 & 19.8 & 19.3 & $2.4-25.5$ & 18.35 & 23.1 \\
\hline SUM & 99.95 & 99.84 & 99.82 & 99.78 & 99.79 & 99.82 & 99.80 & & & \\
\hline
\end{tabular}

Table 2: Values (Wt. \%) of Major elements of the sandstone, clay and shale in Idogun well

\begin{tabular}{|c|c|c|c|c|c|c|c|c|}
\hline Sample no & B1 & B2 & B3 & B4 & B5 & Range & Average & Median \\
\hline Major Oxides & B1 & B2 2 & B3 & D4 & DJ & Kange & Average & medan \\
\hline $\mathrm{SiO}_{2}$ & 59.86 & 83.39 & 42.48 & 94.14 & 45.10 & $42.48-94.14$ & 64.99 & 49.04 \\
\hline $\mathrm{Al}_{2} \mathrm{O}_{3}$ & 19.72 & 7.47 & 18.84 & 1.66 & 16.18 & $1.66-19.72$ & 12.77 & 18.06 \\
\hline $\mathrm{Fe}_{2} \mathrm{O}_{3}$ & 8.68 & 3.71 & 6.08 & 1.04 & 6.58 & $1.04-8.68$ & 5.21 & 7.64 \\
\hline MgO & 0.12 & 0.12 & 1.21 & 0.03 & 0.77 & $0.03-1.21$ & 0.45 & 1.18 \\
\hline $\mathrm{CaO}$ & 0.07 & 0.24 & 9.71 & 0.13 & 11.79 & $0.07-11.79$ & 4.38 & 11.72 \\
\hline $\mathrm{Na}_{2} \mathrm{O}$ & 0.02 & 0.01 & 0.06 & 0.01 & 0.08 & $0.01-0.08$ & 0.03 & 0.07 \\
\hline $\mathrm{K}_{2} \mathrm{O}$ & 0.23 & 0.18 & 1.41 & 0.17 & 0.76 & $0.18-1.41$ & 0.55 & 1.24 \\
\hline $\mathrm{TiO}_{2}$ & 1.3 & 0.38 & 0.9 & 0.27 & 0.9 & $0.27-1.3$ & 0.75 & 1.0 \\
\hline $\mathrm{P}_{2} \mathrm{O}_{5}$ & 0.1 & 0.29 & 0.39 & 0.08 & 0.65 & $0.08-0.39$ & 0.30 & 0.57 \\
\hline MnO & 0.02 & $<0.01$ & 0.02 & $<0.01$ & 0.01 & $<0.01-0.02$ & 0.017 & 0.02 \\
\hline $\mathrm{Cr}_{2} \mathrm{O}_{3}$ & 0.014 & 0.008 & 0.042 & $<0.002$ & 0.037 & $<0.002-0.037$ & 0.025 & 0.04 \\
\hline LOI & 9.7 & 4.1 & 18.7 & 2.4 & 16.90 & $2.4-16.90$ & 10.36 & 16.3 \\
\hline SUM & 99.82 & 99.93 & 99.84 & 99.95 & 99.78 & & & \\
\hline
\end{tabular}

Also from the terrigenous sediment based upon a plot of $\log \left(\mathrm{Na}_{2} \mathrm{O} / \mathrm{K}_{2} \mathrm{O}\right)$ against $\log \left(\mathrm{SiO}_{2} / \mathrm{Al}_{2} \mathrm{O}_{3}\right)$ (petijohn et al., 1972).

It can be observed that the clay and shale samples from both well falls mainly in the litharenite regions, the Idogun sandstone falls within the subarkose and quartzarenite while the lewumeji sandstone falls in the sublitharenite region (Fig.6). The sample that plotted within the quartzarenite region is an indication of the maturity and quartz enrichment in the sample.

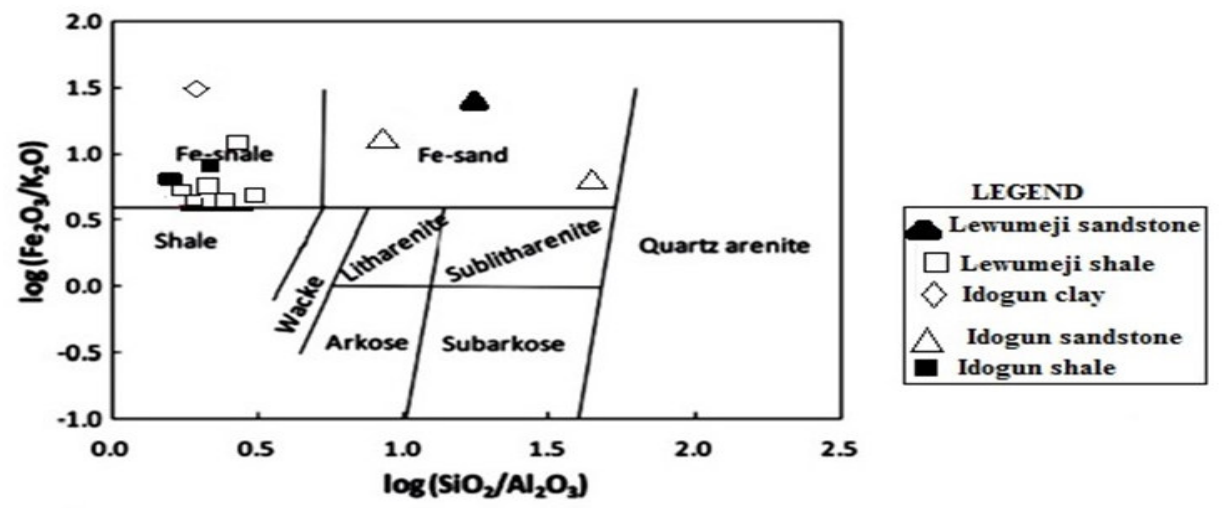

Figure 5: Geochemical classification of sediments from the studied area (After Herron, 1988) 

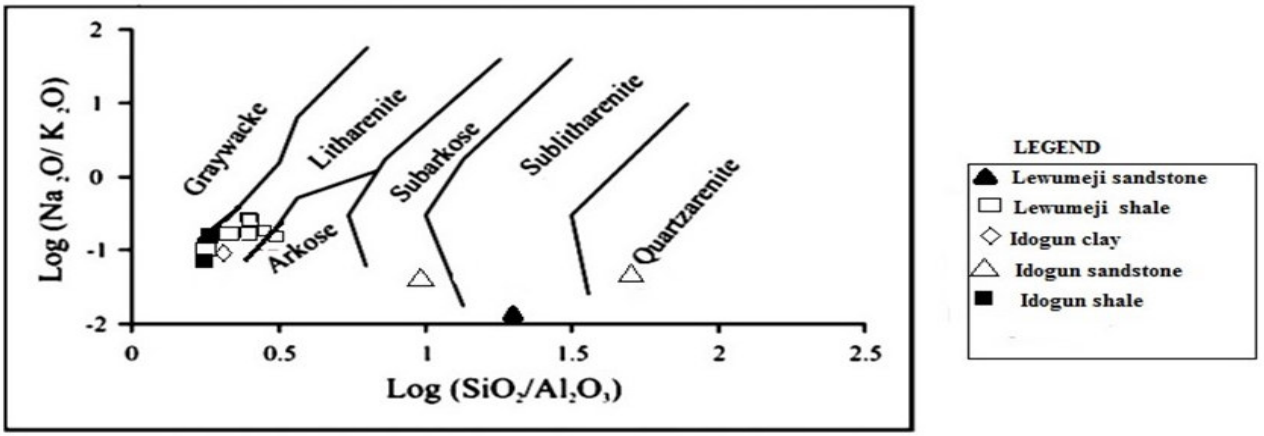

Figure 6: Geochemical classification of sediments from the studied areas (Modified from Pettijohn et al.,1972)

\subsubsection{Source Area weathering}

The weathering indices of ancient sedimentary rocks are useful to evaluate the degree of weathering of rocks from which sediments grains are derived. Chemical weathering indices are commonly used in recent and old weathering profile studies (Kirschbaum et al., 2005; Goldberg and Humayun, 2010). This can be done in part by examining the relationships among the alkali and alkaline earth elements. (Nesbitt and young, 1982). Because the chemical alteration of rocks during weathering results in depletion of alkalis and alkaline earth elements and preferential enrichment of $\mathrm{Al}_{2} \mathrm{O}_{3}$ in sediments(Cingolani et al., 2003). The most widely used indices for quantitative estimation of the degree of weathering in any source region, include the Chemical Index of Alteration (CIA), Plagioclase Index of Alteration (PIA), Chemical Index of weathering (CIW) proposed by Nesbitt and Young, (1982), Fedo et al., (1995), Harnois, (1988) respectively. High CIA and PIA value (75-100) indicate intensive chemical weathering in the source area whereas low values(50 or less) indicates near absence of chemical alteration and reflect cool and / arid condition or unweathered source area (Osae et al., 2006). The intensity of chemical weathering or alteration of sediments source can be calculated using the following formular:

$\mathrm{CIA}=100\left[\mathrm{Al}_{2} \mathrm{O}_{3} /\left(\mathrm{Al}_{2} \mathrm{O}_{3}+\mathrm{CaO}+\mathrm{Na}_{2} \mathrm{O}+\mathrm{K}_{2} \mathrm{O}\right)\right]$

$\mathrm{PIA}=100\left[\left(\mathrm{Al}_{2} \mathrm{O}_{3}-\mathrm{K}_{2} \mathrm{O}\right) /\left(\mathrm{Al}_{2} \mathrm{O}_{3}+\mathrm{CaO}+\mathrm{Na}_{2} \mathrm{O}-\mathrm{K}_{2} \mathrm{O}\right)\right]$

$\mathrm{CIW}=100\left[\mathrm{Al}_{2} \mathrm{O}_{3} /\left(\mathrm{Al}_{2} \mathrm{O}_{3}+\mathrm{CaO}+\mathrm{Na}_{2} \mathrm{O}\right]\right.$.

The CIA, PIA and CIW Values (table 3) for Lewumeji samples range from ( $42.73 \%-94.68 \%, 42.25 \%$ $96.56 \%, 44.08 \%-96.64 \%)$ with averages of $(71.52 \%, 73.80 \%$ and $75.03 \%)$ respectively while Idogun samples range from $(56.16 \%-98.40 \%, 56.54 \%-99.54 \%, 57.68 \%-99.54 \%)$ with an averages of $(79.22 \%, 81.64 \%$ and $82.41 \%$ ). These values are variable and it may be as a result of multiple provenances for sediments which have variable proportions of source area weathering and related processes or may be due to low concentrations of the alkalis and alkaline earth elements. From the two well, majority of the samples show CIA, PIA and CIW values greater than $70 \%$ suggesting moderate to high weathering either at the source or during transport before deposition (McLennan, 1993; Fedo et al., 1995), this show that the sediments are geochemically and texturally mature. The mobility of elements during the progress of chemical weathering can be plotted using the molar proportion of $\mathrm{Al}_{2} \mathrm{O}_{3}, \mathrm{Na}_{2} \mathrm{O}$, and $\mathrm{CaO}^{*}$ (CaO in silicate fraction) in a A-CN-K ternary diagram (Fig.7). The plots shows clusters of data pointing towards the $\mathrm{Al}_{2} \mathrm{O}_{3}$ apex and oriented smoothly parallel to the A-CN join suggesting the removal of $\mathrm{Ca}, \mathrm{Na}$, and $\mathrm{K}$ in the parent material and abundance mineral phase with composition close to Plagioclase feldspar, Smectite and Kaolinite (Ogbahon et al., 2019).

Table 3: Result of CIA, PIA and CIW of the study wells

\begin{tabular}{|l|l|l|l|l|l|}
\hline Sample no & Depth $(\mathbf{m})$ & Lithology & CIA(\%) & PIA (\%) & CIW (\%) \\
\hline A1 & $0.00-15.00$ & Sandstone & 94.5699 & 96.5699 & 96.6408 \\
\hline A2 & $15.00-30.00$ & Shale & 58.4851 & 59.0868 & 60.4880 \\
\hline A3 & $30.00-45.00$ & Shale & 42.7347 & 42.2591 & 44.0884 \\
\hline A4 & $45.00-60.00$ & Shale & 65.2680 & 67.7506 & 70.1754 \\
\hline A5 & $60.00-75.00$ & Shale & 72.1524 & 74.7019 & 76.0784 \\
\hline A6 & $75.00-90.00$ & Shale & 84.7733 & 89.1996 & 89.8458 \\
\hline A7 & $90.00-111$ & Shale & 82.5921 & 87.0843 & 87.9170 \\
\hline B1 & $0.00-9.00$ & Claystone & 98.4031 & 99.5403 & 99.5456 \\
\hline B2 & $9.00-15.00$ & Sandstone & 94.5569 & 96.6843 & 96.7616 \\
\hline B3 & $15.00-24.00$ & Shale & 62.7581 & 64.0808 & 65.8511 \\
\hline B4 & $24.00-42.00$ & Sandstone & 84.2639 & 91.4110 & 92.2222 \\
\hline B5 & $42.00-54.00$ & Shale & 56.1610 & 56.5042 & 57.6827 \\
\hline
\end{tabular}




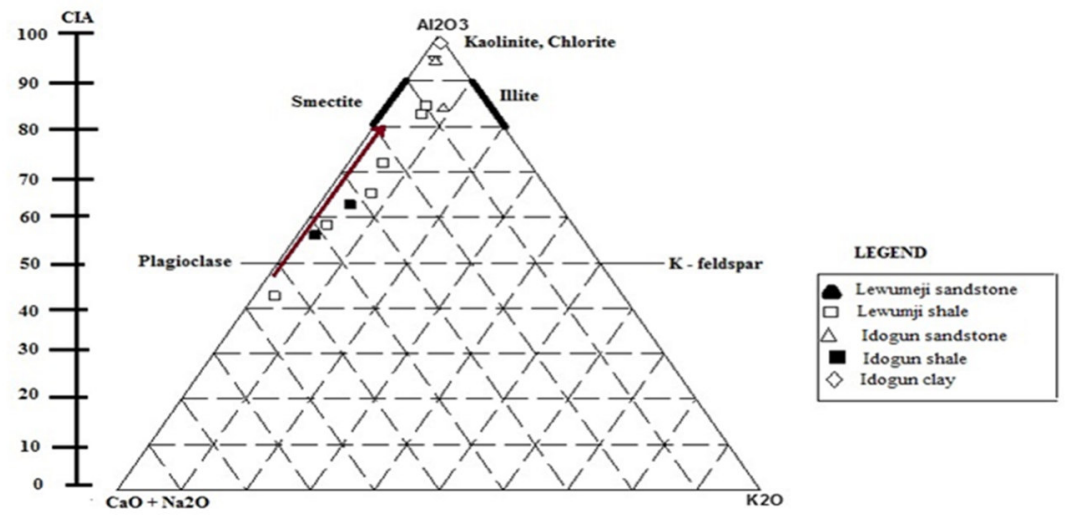

Figure 7: A-CN-K ternary diagram showing weathering trends of the study wells.(modified from Nesbitt and Young, 1982; Fedo et al., 1995)

\subsubsection{Depositional Environment}

The depositional environments for sediment of the study wells were classified on the basis of Englung and Jorgensen, (1973) ternary plot. This involve the chemical classification on the basis of $\left(\mathrm{Al}_{2} \mathrm{O}_{3}\right)-\left(\mathrm{K}_{2} \mathrm{O}+\mathrm{Na}_{2} \mathrm{O}+\right.$ $\mathrm{CaO})-\left(\mathrm{Fe}_{2} \mathrm{O}_{3}+\mathrm{MgO}\right)$ content $(\mathrm{AKF})$. From the AKF plots (fig 8), Lewumeji sandstone, Lewumeji shale, Idogun sandstone and Idogun claystone falls under the continental zone while the Idogun shale and one shale sample of Lewumeji well falls in the transitional zone. The sediments are gradually moving from the continental environment to the transitional environment indicating a shallow marine environment and the sediment underwent high to transportation under oxidizing conditions (Adeigbe and Jimoh, 2013).

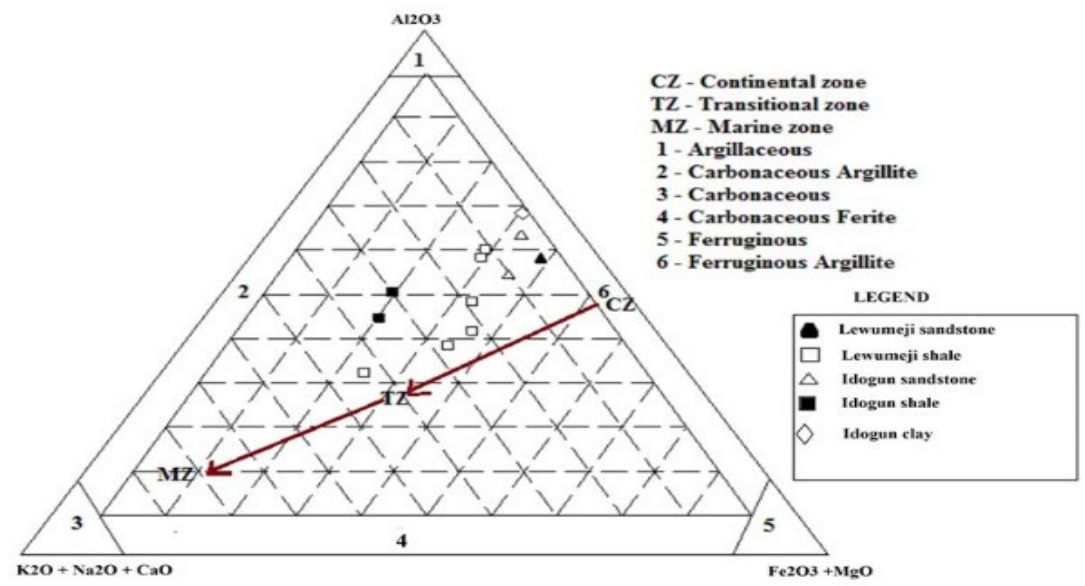

Figure 8: $\left(\mathrm{Al}_{2} \mathrm{O}_{3}\right)-\left(\mathrm{K}_{2} \mathrm{O}+\mathrm{Na}_{2} \mathrm{O}+\mathrm{CaO}\right)-\left(\mathrm{Fe}_{2} \mathrm{O}_{3}+\mathrm{MgO}\right)(\mathrm{AKF})$ ternary plot between depositional environment ( after Englung and Jorgensen, 1973)

\subsubsection{Provenance Indices}

The main aim of sedimentary provenance studies are to reconstruct and to interpret the history of sediment from the initial erosion of parent rocks to the final burial of their detritus. The provenance discriminant function plot used for this study defined four (4) main provenance zones; mafic Igneous provenance (basaltic and subordinate andesitic detritus), Intermediate,Igneous provenance (dominantly andesitic detritus), Felsic Igneous provenance (acidic, plutonic and volcanic detritus) and quartzose sedimentary provenance (recycled detritus).

Roser and Korsch, (1986) introduced two major element discriminant function diagram to constrain provenance and compositions of source rock. The first is the use of oxides of $\mathrm{Ti}, \mathrm{Al}, \mathrm{Fe}, \mathrm{Mg}, \mathrm{Ca}, \mathrm{Na}$ and $\mathrm{K}$ to effectively differentiate the sediments into four zones and the discriminant functions based upon the ratios of individual $\mathrm{TiO}_{2}, \mathrm{MgO}, \mathrm{Fe}_{2} \mathrm{O}_{3}$, and $\mathrm{K}_{2} \mathrm{O}$ to $\mathrm{Al}_{2} \mathrm{O}_{3}$. The ratio plot is not as effective as the one base on raw oxides. In the ratio plot biogenic $\mathrm{CaO}$ and $\mathrm{SiO}_{2}$ in provenance determination could be eliminated. Using the formula for DF1 and DF2, certain conclusion and deductions were made;

Discriminiant Function $(\mathbf{D F} 1)=-1.773 \mathrm{TiO}_{2}+0.607 \mathrm{Al}_{2} \mathrm{O}_{3}+0.76 \mathrm{Fe}_{2} \mathrm{O}_{3(\mathrm{~T})}-1.5 \mathrm{MgO}+0.616 \mathrm{CaO}+0.509 \mathrm{Na}_{2} \mathrm{O}$ $-1.224 \mathrm{~K}_{2} \mathrm{O}-9.09$

Discriminiant Function (DF2) $=0.445 \mathrm{TiO}_{2}+0.07 \mathrm{Al}_{2} \mathrm{O}_{3}-0.25 \mathrm{Fe}_{2} \mathrm{O}_{3(\mathrm{~T})}-1.42 \mathrm{MgO}+0.438 \mathrm{CaO}+1.475 \mathrm{Na}_{2} \mathrm{O}$ $+1.426 \mathrm{~K}_{2} \mathrm{O}-6.861$ 
Discriminiant Function (DF1) $=30.638 \mathrm{TiO}_{2} / \mathrm{AL}_{2} \mathrm{O}_{3}-12.541 \mathrm{Fe}_{2} \mathrm{O}_{3(\mathrm{~T})} / \mathrm{AL}_{2} \mathrm{O}_{3}+7.329 \mathrm{MgO} / \mathrm{AL}_{2} \mathrm{O}_{3}+12.031$ $\mathrm{Na}_{2} / \mathrm{AL}_{2} \mathrm{O}_{3}+35.402 \mathrm{~K}_{2} \mathrm{O} / \mathrm{AL}_{2} \mathrm{O}_{3}-6.382$

Discriminiant Function $(\mathbf{D F} 2)=56.500 \mathrm{TiO}_{2} / \mathrm{AL}_{2} \mathrm{O}_{3}-10.879 \mathrm{Fe}_{2} \mathrm{O}_{3(\mathrm{~T})} / \mathrm{AL}_{2} \mathrm{O}_{3}+30.875 \mathrm{MgO} / \mathrm{AL}_{2} \mathrm{O}_{3}-5.404$ $\mathrm{Na}_{2} \mathrm{O} / \mathrm{AL}_{2} \mathrm{O}_{3}+11.112 \mathrm{~K}_{2} \mathrm{O} / \mathrm{AL}_{2} \mathrm{O}_{3}-3.89$

The plots using raw oxides (Fig 9) show that the study sediments from the two wells (Idogun and Lewumeji well) were sourced mainly from Mafic igneous rock and Quartzose sedimentary provenance implying a mixed source. The lewumeji shale, Idogun shale and clay plotted within the the mafic igneous provenance while the Idogun sandstone,lewumeji sandstone and few of lewumeji shale plotted within the quartzose sedimentary zone while the ratio plots (fig 10) shows the sediments plotting in the four zones (quartzose sedimentary zone, mafic, felsic and intermediate zone). In this case the mafic input also must have come from first cycle basaltic and minor andesitic detritus and the recycled sources represent quartzose sediments of mature continental provenance and the derivation of the sediments could be from a highly weathered granite-gneiss terrain and or from a pre-existing sedimentary terrain.(Roser and Korsch 1988),

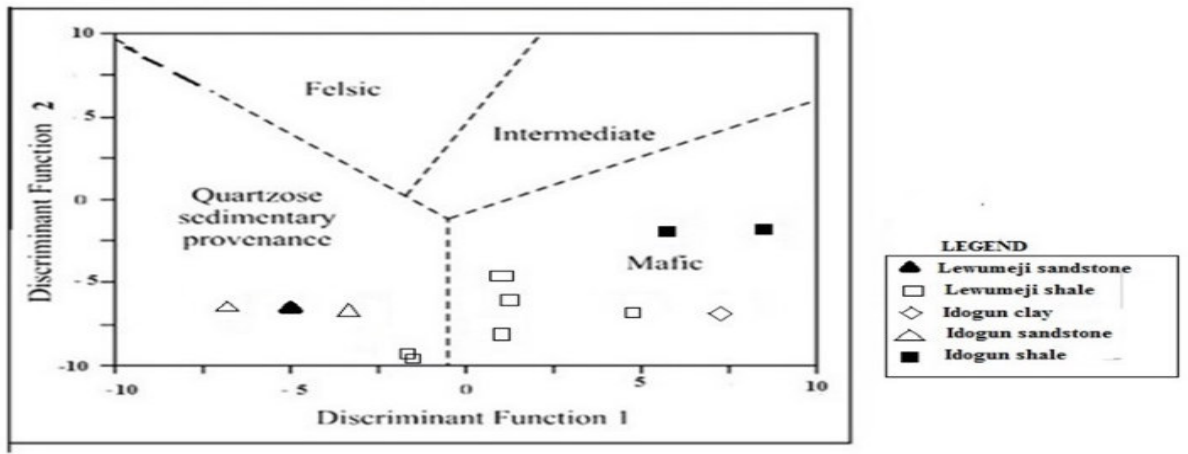

Fig. 9: Discriminant function diagram for the provenance indices of the study wells using raw oxide (after Roser and Korsch, 1988)

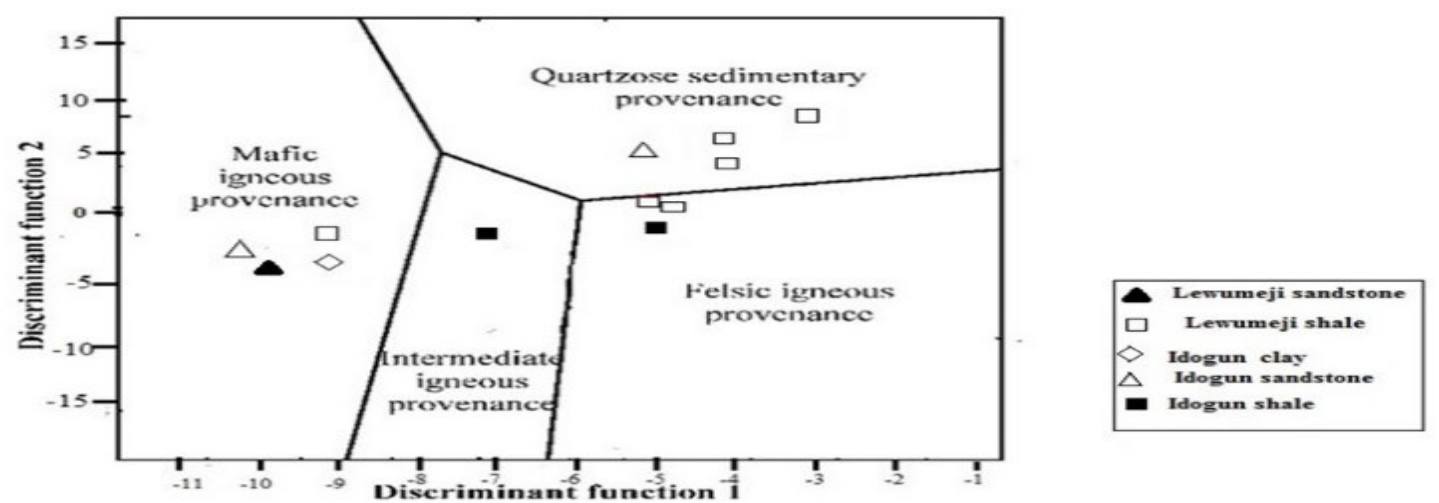

Fig. 10: Discriminant function diagram for the provenance indices of the study wells using ratio plot (after Roser and Korsch, 1988).

\subsubsection{Tectonic setting}

Tectonic settings impart a distinctive geochemical signature to sediments because different tectonic environments has distinct provenance characteristics and distinct sedimentary process. Sedimentary basins may be assigned to Active continental margin (ACM), Passive continental margin (PCM), Oceanic Island arc (OIC) and Continental Island- arc (CIA). (Bhatia, 1983). The ACM are those that are tectonically active which are marked by earthquakes, volcanoes while PCM are developed along coastlines that are not tectonically active.

Discrimination diagram based on bivariate plot of first and second discriminate functions of major element analysis of the sediment within the study well (after Bhatia,1983) were plotted to delineate the tectonic settings. The formular for discriminant function is as follows:

Discriminant function $\mathbf{1}=-0.0447 \mathrm{SiO}_{2}-0.972 \mathrm{TiO}_{2}+0.008 \mathrm{Al}_{2} \mathrm{O}_{3}-0.267 \mathrm{Fe}_{2} \mathrm{O}_{3}+0.208 \mathrm{FeO}-3.082 \mathrm{MnO}+$ $0.140 \mathrm{MgO}+0.195 \mathrm{CaO}+0.719 \mathrm{Na}_{2} \mathrm{O}-0.032 \mathrm{~K}_{2} \mathrm{O}+7.510 \mathrm{P}_{2} \mathrm{O}_{5}+0.303$

Discriminant function $2=-0.421 \mathrm{SiO}_{2}+1.988 \mathrm{TiO}_{2}-0.526 \mathrm{Al}_{2} \mathrm{O}_{3}-0.551 \mathrm{Fe}_{2} \mathrm{O}_{3}-1.610 \mathrm{FeO}+2.720 \mathrm{MnO}+$ $0.881 \mathrm{MgO}-0.907 \mathrm{CaO}-0.177 \mathrm{Na}_{2} \mathrm{O}-1.840 \mathrm{~K}_{2} \mathrm{O}+7.244 \mathrm{P}_{2} \mathrm{O}_{5}+43.57$

From the plot (fig 11), both sediment from Idogun well and Lewumeji well fall within the passive margin. This is 
also in agreement with the plot of $\mathrm{K}_{2} \mathrm{O} / \mathrm{Na}_{2} \mathrm{O}$ vs $\mathrm{SiO}_{2}$ discriminant diagram of Roser and Korsch (1986) which shows the sediments were found within the passive continental margin (fig 12)

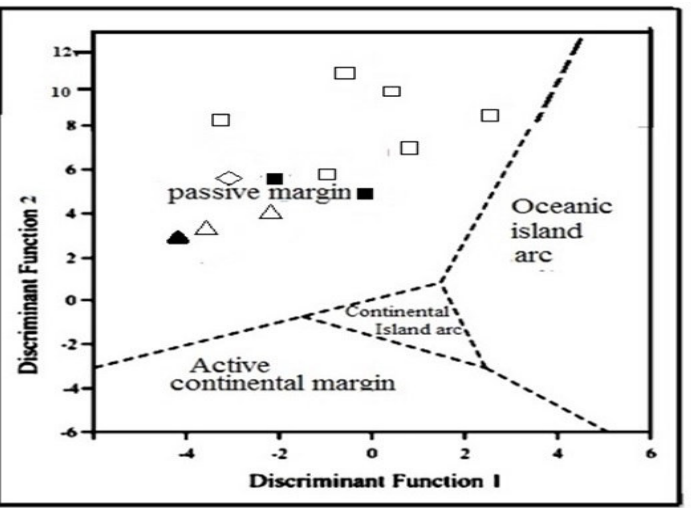

LEGEND

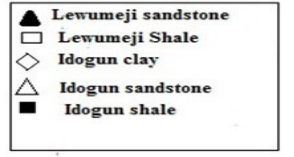

Fig. 11: The discriminant function diagram (After Bhatia, 1983) showing fields for sediments of Lewumeji well and Idogun well.

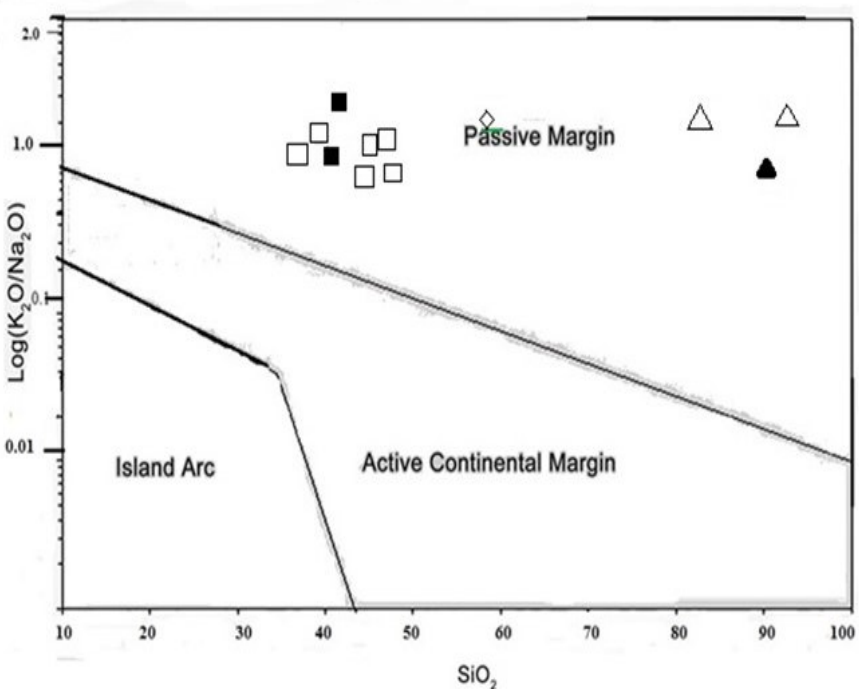

LEGEND

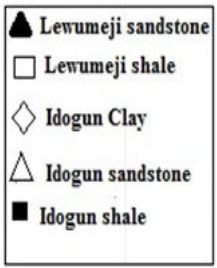
$\square$ Lemumeji shale $\triangle$ Idogun Clay

Idogun shale

Fig. 11: $\log \left(\mathrm{K}_{2} \mathrm{O} / \mathrm{Na}_{2} \mathrm{O}\right)$ against $\mathrm{SiO}_{2}$ discriminant diagram showing the field of passive margin, active continental margin and Island arc (After Roser and Korsch, 1986)

\subsection{Trace Element Geochemistry}

The trace element concentrations in sediments result from the influence of provenance, weathering, diagenesis etc. Certain trace elements because of their relatively low mobility have been used to distinguish depositional environment, source rock composition and tectonic setting. The immobile trace elements $(\mathrm{Zr}, \mathrm{Y}, \mathrm{Hf}, \mathrm{Nb})$ are useful for provenance and tectonic setting determinations (Bhatia and Crook, 1986). The trace element concentration for Lewumeji well is enriched in $\mathrm{Ba}(22-147 \mathrm{ppm}$; average $=110.2 \mathrm{ppm}), \mathrm{Sr}(14.8-295.8 \mathrm{ppm}$; average $=203.5), \mathrm{V}$ $(33-178 \mathrm{ppm}$; average $=136.8 \mathrm{ppm})$ and $\mathrm{Zr}(139.3-307.6 \mathrm{ppm}$; average $=189.8 \mathrm{ppm})$. While the Idogun well is enriched in $\mathrm{Zr}(177.4$ - 813.4ppm; average $=394.94)$, Sr (42.8 - 506.4ppm; average $=169.8 \mathrm{ppm})$, Ba $(53-145 \mathrm{ppm}$; average $=92.2 \mathrm{ppm})$ and $\mathrm{V}(14-119 \mathrm{ppm}$; average $=85.2 \mathrm{ppm})$. The high vanadium level in most of the samples is an indication of input of mafic igneous particles in the sediment and the average Sr value in Lewumeji well is higher than the Sr value for PAAS, NASC and UCC (Table 4).

Both lewumeji and Idogun wells are positively correlated with $\mathrm{Al}_{2} \mathrm{O}_{3}(\mathrm{R}=0.95,0.77, \mathrm{R}=0.99,0.96, \mathrm{R}=0.98$, 0.68 , and $\mathrm{R}=0.97,0.97$ ). Which suggest that this elements are linked with Clay mineral. Also, the significant correlation of $\mathrm{Ba}$ with $\mathrm{K}_{2} \mathrm{O}$ suggests that $\mathrm{Ba}$ is mainly associated with feldspar since it is an alkaline metal. 
Table 4: Comparison of average trace element composition of the study wells with other published average.

\begin{tabular}{|c|c|c|c|c|c|}
\hline Trace Element & \multicolumn{3}{|c|}{ Present study } & & \\
\hline & $\begin{array}{c}\text { Lewumeji } \\
\text { Average }\end{array}$ & Idogun average & UCC & PAAS & NASC \\
\hline $\mathrm{Ba}$ & 110.2 & 92.2 & 550 & 650 & 630 \\
\hline $\mathrm{Sr}$ & 203.5 & 169.8 & 190 & 210 & 200 \\
\hline $\mathrm{V}$ & 136.8 & 85.2 & 130 & 150 & 60 \\
\hline $\mathrm{Zr}$ & 189.8 & 394.9 & 190 & 210 & 200 \\
\hline $\mathrm{Zn}$ & 4 & 19.2 & 27 & 35 & 22 \\
\hline $\mathrm{Ni}$ & 8.11 & 82.8 & 71.0 & 85.0 & - \\
\hline $\mathrm{Nb}$ & 36.8 & 13.8 & 20 & 55 & 58 \\
\hline $\mathrm{Sc}$ & 19.1 & 14.9 & 25 & 19 & 13 \\
\hline $\mathrm{Co}$ & 10.8 & 9.2 & 11.0 & 16.0 & 14.9 \\
\hline $\mathrm{Rb}$ & 48.7 & 6.1 & 10.0 & 23.0 & 25.7 \\
\hline $\mathrm{Th}$ & 9.8 & 24.7 & 112 & 160 & 125 \\
\hline $\mathrm{U}$ & 2.6 & 12.3 & 10.7 & 14.6 & 12.3 \\
\hline $\mathrm{Ta}$ & 1.28 & 5.1 & 2.8 & 3.1 & 2.66 \\
\hline $\mathrm{Hf}$ & 4.94 & 1.12 & 2.2 & - & 12.3 \\
\hline $\mathrm{Ba} / \mathrm{Co}$ & 12.2 & 10.16 & 5.8 & 5 & 6.3 \\
\hline $\mathrm{Sr} / \mathrm{Ba}$ & 1.74 & 23.6 & 55.0 & 28.6 & - \\
\hline $\mathrm{Th} / \mathrm{Sc}$ & 0.96 & 1.55 & - & - & - \\
\hline $\mathrm{Zr} / \mathrm{Sc}$ & 26.93 & 7.31 & - & - & - \\
\hline $\mathrm{Tecton}$ & & - & - & - \\
\hline
\end{tabular}

\subsubsection{Provenance and Tectonic setting}

The concentration of $\mathrm{Zr}$ is used to characterize the nature and source rock composition (Hayashi et al., 1997; Paikaray et al., 2008). The $\mathrm{TiO}_{2} / \mathrm{Zr}$ ratios can be used to differentiate between the three (3) different source rock types, i.e., felsic, intermediate and mafic. The $\mathrm{TiO}_{2}$ versus $\mathrm{Zr}$ plot (Fig. 12) shows Idogun samples plotting in the Mafic, intermediate and a sample of sandstone in felsic zone while the Lewumeji samples plotted in the Mafic and Intermediate zone. The abundance of $\mathrm{Th}, \mathrm{Y}, \mathrm{Zr}$ and $\mathrm{Nb}$ in source rocks will increase as their chemistry becomes more developed (Madukwe et al., 2016). Th/Sc ratio is a sensitive index of the bulk composition of the source, $\mathrm{Th} / \mathrm{Sc}$ ratio for post-Archean rocks is usually 1, and greater than 1 for granitic rocks; for Archean and basic rocks the ratio is less than 1 (Taylor and McLennan, 1985). The Th/Sc ratio of lewumeji and Idogun sediments averages 0.96 and 1.31 respectively, this suggest that lewumeji sediments may have come from Mafic source while the Idogun sediments is likely to be from the granitic rocks.

$\mathrm{Zr} / \mathrm{Sc}$ ratio is highly sensitive to accumulation of zircon and can be used to identify heavy mineral concentrations (Taylor and McLennan, 1985). The average $\mathrm{Zr} / \mathrm{Sc}$ ratio of the Idogun sediments is 70.1 and 26.9 for the Lewumeji sediments. These values are lower than the UCC and PAAS values suggesting that the sediments are moderately enriched in zircon. All elements involved in the ratios are also resistant to weathering processes (Taylor and McLennan, 1985)

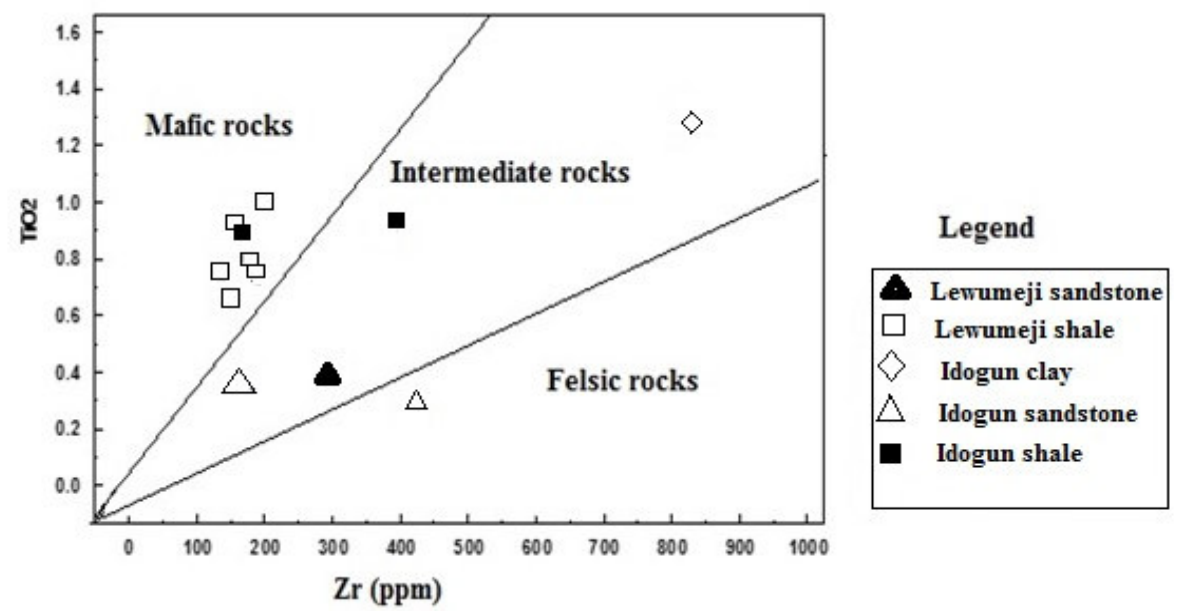

Fig. 12: $\mathrm{TiO}_{2}-\mathrm{Zr}$ plot for the sediments in Lewumeji well and Idogun well (After Hayashi et al., 997)

The U/Th and Ni/Co ratio are sensitive to the paleoredox conditions of ancient sediments (Nagarajan et al., 2007, Rimmer, 2004). Sedimentary rocks derived from oxic conditions are characterized by U/Th ratio below 1.25 
whereas values above 1.25 suggest suboxic and anoxic condition. (Nath et al., 2000). The U/Th ratio for Idogun and lewumeji sediments ranges between $0.15-1.04$ and $0.20-0.36$ respectively indicating that the sediments were deposited in an oxic environment. Dypvik, (1984) and Dill, (1986) have used Ni /Co ratio as a redox indicator. However, it is noted that $\mathrm{Ni} / \mathrm{Co}$ ratio can easily be altered by diagenetic reactions. $\mathrm{Ni} / \mathrm{Co}$ ratio below 5 indicate oxic environments, whereas ratios above 5 indicate suboxic and anoxic environments (Jones and manning, 1994). Thus Ni/Co ratio ranges between 0.75 - 2.94 and $1.43-1.91$ for the Idogun and Lewumeji sediments respectively suggesting an oxic environment.

According to Bhatia and Crook (1986) Th- Sc- Zr/10 and Th, Co and Zr/10 concentration can be used to discriminate sediments derived from oceanic Island arc, continental Island arc and passive and active continental margins. From the ternary plots of Th- Co- Zr/10 (Fig 13), the Lewumeji shale, Idogun shale and sandstone plotted in the continental Island arc while the Idogun clay and shale plotted in the passive margin. From the $\mathrm{Th}-\mathrm{Sc}-$ $\mathrm{Zr} / 10$ plot (fig 14) all the shale samples from both well and Idogun sandstone plotted in the continental Island arc and the Idogun clay plotted in the passive margin region.

Both plot indicate that the Idogun clay is derived from passive margin while the shale from both well and a sandstone from is derived from continental island arc.

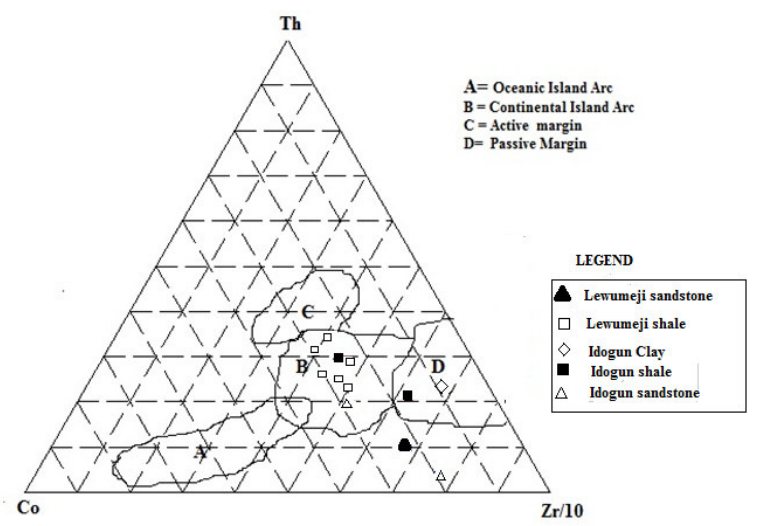

Fig. 13: Th- Co - Zr/10 plots for sediments of Lewumeji and Idogun well (After Bhatia and crook, 1986)

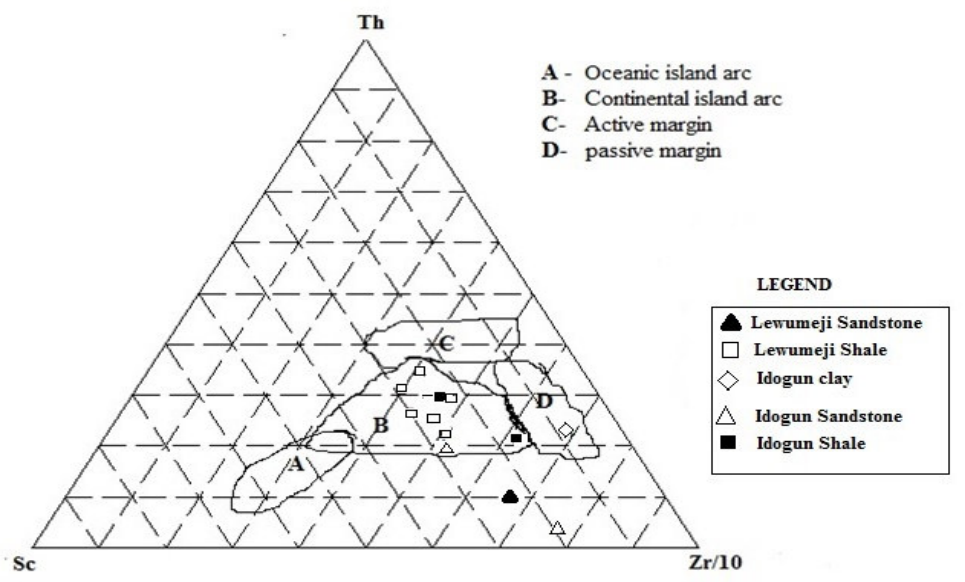

Fig. 14: Th- Sc -Zr/10 plots for sediments of Lewumeji and Idogun well (After Bhatia and crook, 1986)

\subsection{Rare Earth Element Geochemistry (REEs)}

These are the least soluble trace element which are relatively immobile during low-grade metamorphism, weathering and the residence times of REEs in seawater are short (50-600 years) (McLennan et al., 1993,). They are effective indicators of sediment source when compared to Upper continental crust (UCC), Mantle material and Oceanic crust. Rare earth element are highly resistant to fractionation during weathering and diagenesis, their low solubility and short residence time in ocean makes them to be preserved in terrigenous sediment and validate their use as provenance indicator (Sethi et al., 1998). Because of near quantitative transfer of REE from a source region to the depositional site, terrigenous sediments reflect the average composition of source rocks.

The Light rare earth element (LREE) has atomic no 57 to 61, while the heavy rare earth elements (HREE) has atomic no 62 to 71 . Their abundance in rocks are usually normalized to a common reference standard and are then expressed as the logarithm to the base 10 of the value, which are mostly made up of the values for chondritic meteorites. The chondrite normalization remove the abundance of variation (Zig-Zag pattern) between even and 
odd atomic elements and also allows any fractionation of the REE group relative to chondrite meteorites to be identified. Distribution of the sediments normalized to chondrite values (in ppm) are plotted against the atomic numbers of rare earth element (fig. 15a and b) which produce a Europium anomaly. The chondrite normalizing factor from Sun and Mcdonough, (1989).

The Lewumeji sediments and Idogun sediments show large variation in REE contents $(49.33-235.34 \mathrm{ppm})$ and $(37.29-269 \mathrm{ppm})$ respectively. In the study wells there is high enrichment of Light rare earth element (La, $\mathrm{Ce}$ and $\mathrm{Nd}$ ) to heavy rare earth element (Er, Dy and Gd). The light rare earth element like Tb, Ho, Tm and Lu are the least enriched. (Table 5). Chondrite normalised $(\mathrm{Gd} / \mathrm{Yb})_{\mathrm{N}}$ ratio of sandstone, clay and shale in the study well is low $(1.10-2.20)$ for lewumeji sediments and $(1.34-2.32)$ for Idogun sediments which suggest that the sediments are derived from HREE depleted source rocks and the ratios of LREE/HREE, $(\mathrm{Ce} / \mathrm{Yb})_{\mathrm{N}},(\mathrm{La} / \mathrm{Yb})_{\mathrm{N}}$, values are higher in Lewumeji sandstone ( $14.4,14.7$ and 15.9) and Idogun sandstone (11.3, 11.5 and 15.9) respectively than in Lewumeji shale $(10.1,11.1$, and 14.1) and Idogun shale $(9.4,10.6$ and 12.62) respectively indicating that the REE in sandstone is more fractionated than in shale, however, the higher REE content in the sandstone maybe due to dominance of fine sand, silt and clay fractions (Cullers et al .,1974, Taylor and McLennan, 1985) .

Table 5: Values of Rare earth element (REE) compositions in the study area

\begin{tabular}{|c|c|c|c|c|c|c|c|c|c|c|c|c|}
\hline Sample no / & \multicolumn{7}{|c|}{ LEWUMEJI WELL } & \multicolumn{5}{|c|}{ IDOGUN WELL } \\
\hline Element & $\mathrm{A} 1$ & $\mathrm{~A} 2$ & $\mathrm{~A} 3$ & A4 & A5 & A6 & A7 & B1 & B2 & B3 & B4 & B5 \\
\hline $\mathrm{La}$ & 13.3 & 37.5 & 32.9 & 22.8 & 15.9 & 18.5 & 23.8 & 82.7 & 47.5 & 44.6 & 8.7 & 51.9 \\
\hline $\mathrm{Ce}$ & 23.1 & 74.1 & 58.7 & 92 & 69.3 & 97.2 & 102.1 & 125.2 & 90.1 & 87.7 & 15.9 & 112.9 \\
\hline $\operatorname{Pr}$ & 1.98 & 8.02 & 6.32 & 9.67 & 7.47 & 97.2 & 10.81 & 11.37 & 10.1 & 9.3 & 1.51 & 12.62 \\
\hline $\mathrm{Nd}$ & 6.7 & 31.6 & 21.9 & 37.4 & 28.3 & 38.6 & 42 & 32.8 & 35.3 & 36.6 & 6.1 & 53.1 \\
\hline $\mathrm{Sm}$ & 1.06 & 5.51 & 4.41 & 6.64 & 4.94 & 7.19 & 7.84 & 4.66 & 5.24 & 6.83 & 1.15 & 9.36 \\
\hline $\mathrm{Eu}$ & 0.19 & 1.23 & 1.04 & 1.48 & 1.14 & 1.53 & 1.65 & 0.82 & 0.95 & 1.55 & 0.22 & 2.02 \\
\hline $\mathrm{Gd}$ & 0.8 & 5.09 & 3.97 & 5.81 & 4.46 & 5.81 & 6.4 & 3.58 & 4.24 & 5.39 & 1.09 & 8.37 \\
\hline $\mathrm{Tb}$ & 0.13 & 0.73 & 0.61 & 0.84 & 0.63 & 0.82 & 0.89 & 0.54 & 0.57 & 0.8 & 0.16 & 1.2 \\
\hline Dy & 0.61 & 3.79 & 3.32 & 4.68 & 3.52 & 4.09 & 4.74 & 3.16 & 3.27 & 4.34 & 0.81 & 6.49 \\
\hline Ho & 0.16 & 0.74 & 0.66 & 0.9 & 0.65 & 0.78 & 0.88 & 0.62 & 0.6 & 0.88 & 0.19 & 1.34 \\
\hline Er & 0.52 & 2.21 & 1.65 & 2.49 & 1.76 & 2.11 & 2.28 & 1.8 & 1.69 & 2.45 & 0.58 & 3.62 \\
\hline $\mathrm{Tm}$ & 0.08 & 0.3 & 0.26 & 0.35 & 0.25 & 0.31 & 0.34 & 0.26 & 0.24 & 0.35 & 0.1 & 0.49 \\
\hline $\mathrm{Yb}$ & 0.60 & 2.03 & 1.7 & 2.18 & 1.7 & 2.23 & 2.41 & 2.1 & 1.51 & 2.41 & 0.67 & 3.11 \\
\hline $\mathrm{Lu}$ & 0.1 & 0.28 & 0.23 & 0.3 & 0.25 & 0.27 & 0.3 & 0.32 & 0.22 & 0.34 & 0.11 & 0.48 \\
\hline$\sum$ REE & 49.33 & 173.13 & 137.67 & 209.44 & 157.97 & 219.31 & 235.34 & 269.9 & 201.5 & 203.5 & 37.29 & 267 \\
\hline$\sum$ LREE/ $/$ HREE & 14.46 & 9.55 & 9.24 & 10.00 & 10.00 & 11.21 & 10.83 & 19.4 & 14.15 & 9.99 & 8.48 & 8.84 \\
\hline $\mathrm{Eu} / \mathbf{E u} \mathbf{u}^{*}$ & 0.63 & 0.71 & 0.75 & 0.72 & 0.74 & 0.72 & 0.71 & 0.61 & 0.61 & 0.78 & 0.60 & 0.69 \\
\hline $\mathrm{Ce} / \mathrm{Ce}^{*}$ & 1.10 & 1.04 & 0.99 & 1.08 & 1.07 & 1.08 & 1.04 & 1.00 & 1.00 & 1.05 & 1.07 & 1.08 \\
\hline$(G d / Y b)_{N}$ & 1.10 & 2.07 & 1.93 & 2.20 & 2.17 & 2.15 & 2.19 & 1.41 & 2.32 & 1.85 & 1.34 & 2.22 \\
\hline$(\mathrm{La} / \mathrm{Yb})_{\mathrm{N}}$ & 15.90 & 13.25 & 13.88 & 14.70 & 14.17 & 15.56 & 15.68 & 28.24 & 22.56 & 13.27 & 9.31 & 11.97 \\
\hline$(\mathrm{La} / \mathrm{Sm})_{\mathrm{N}}$ & 8.10 & 4.39 & 4.81 & 4.34 & 4.39 & 4.34 & 4.49 & 11.45 & 5.85 & 4.21 & 4.88 & 3.57 \\
\hline$(\mathrm{Ce} / \mathrm{Yb})_{\mathrm{N}}$ & 10.69 & 10.13 & 9.59 & 11.72 & 11.32 & 12.10 & 11.7 & 16.56 & 16.57 & 10.10 & 6.59 & 10.08 \\
\hline
\end{tabular}

$\mathrm{Eu} / \mathrm{Eu}^{*}$ is a parameter used to evaluate the abundances of plagioclase in an igneous or its sedimentary derivative (McLennan et al., 1990). Europium (Eu) value greater than 1.0 indicate a positive anomaly and Eu value less than 0.9 indicate negative anomaly (Adeigbe and Jimoh, 2013). As shown in (table 6), the mean value for Eu anomaly of the Idogun and Lewumeji sediments is 0.66 and 0.71 respectively, which is quite typical to that of UCC (0.65) and PAAS (0.66), indicating a negative Eu anomaly. The enrichment of LREE and moderately negative Eu anomaly reflect their relative abundance in the upper continental crust (Goldschmidt, 1954).

Cerium anomaly $\left(\mathrm{Ce} / \mathrm{Ce}^{*}\right)$ can be used to infer the environmental conditions at the time of deposition since higher values (>1.0) tentatively depict an oxidizing environment (Piper, 1974; Milodowski and Zalasiewicz, 1991; McDaniel et al., 1994). The Ce anomaly for the study well ranges between $0.99-1.10$ for Lewumeji and $1.00-$ 1.08 for Idogun indicating an oxidising environment. The Higher LREE/HREE ratios and the negative Eu anomaly are generally found in felsic rocks while Mafic rocks have a lower LREE/HREE ratios and positive Eu anomaly (Cullers, 1995). Higher LREE/HREE and negative Eu anomalies is an indication of a felsic source of the study area. 
Table 6 : Summary of Chondrite normalized REE values for the studied area.

\begin{tabular}{|c|c|c|c|c|c|c|}
\hline \multirow{2}{*}{$\begin{array}{l}\text { Rare earth } \\
\text { element }\end{array}$} & \multicolumn{3}{|c|}{ LEWUMEJI WELL } & \multicolumn{3}{c|}{ IDOGUN WELL } \\
\cline { 2 - 7 } & Minimum & Maximum & Mean & Minimum & Maximum & Mean \\
\hline $\mathrm{La}$ & 56.1 & 222.4 & 158.6 & 36.71 & 348.9 & 198.6 \\
\hline $\mathrm{Ce}$ & 37.7 & 166.8 & 120.6 & 25.98 & 204.6 & 141.1 \\
\hline $\mathrm{Pr}$ & 20.8 & 113.8 & 81.5 & 15.89 & 132.7 & 94.53 \\
\hline $\mathrm{Nd}$ & 14.3 & 89.9 & 63.2 & 13.1 & 114 & 70.1 \\
\hline $\mathrm{Sm}$ & 6.9 & 51.2 & 35.1 & 7.52 & 61.2 & 35.6 \\
\hline $\mathrm{Eu}$ & 3.2 & 28.4 & 20.3 & 3.1 & 34.8 & 19.2 \\
\hline $\mathrm{Gd}$ & 3.8 & 31.1 & 22.4 & 5.3 & 40.7 & 22.0 \\
\hline $\mathrm{Tb}$ & 3.4 & 23.8 & 17.8 & 4.28 & 32.1 & 17.5 \\
\hline $\mathrm{Dy}$ & 2.4 & 18.7 & 13.9 & 3.19 & 25.6 & 14.2 \\
\hline $\mathrm{Ho}$ & 2.8 & 15.5 & 12 & 3.36 & 23.7 & 12.8 \\
\hline $\mathrm{Er}$ & 3.1 & 15.0 & 11.2 & 3.5 & 21.8 & 12.2 \\
\hline $\mathrm{Tm}$ & 2.2 & 9.7 & 7.5 & 2.72 & 13.6 & 8 \\
\hline $\mathrm{Yb}$ & 3.5 & 14.1 & 10.7 & 3.9 & 18.2 & 11.5 \\
\hline $\mathrm{Lu}$ & 3.9 & 11.8 & 9.73 & 4.3 & 18.9 & 11.6 \\
\hline $\mathrm{Eu} / \mathrm{Eu} *$ & 0.63 & 0.75 & 0.71 & 0.60 & 0.78 & 0.66 \\
\hline $\mathrm{Ce} / \mathrm{Ce} *$ & 0.99 & 1.10 & 1.06 & 1.00 & 1.08 & 1.04 \\
\hline
\end{tabular}

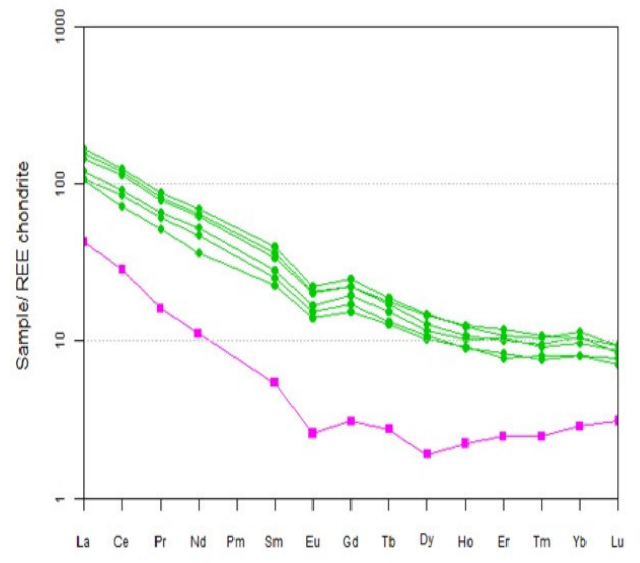

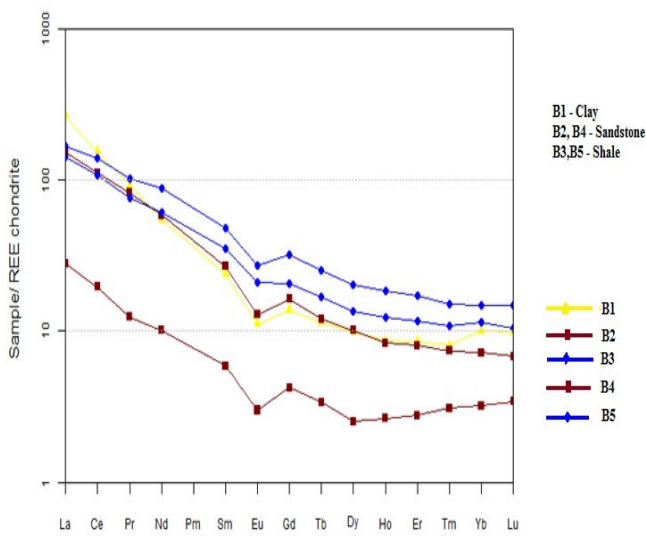

b.

Fig. 15: Chondrite normalized rare earth elemental plot of sediments from (a)Lewumeji well (b) Idogun well

\section{Conclusions}

The Lithostratigraphy and geochemical analysis has been appropriately employed to study the sediments of Abeokuta group a part of Eastern Dahomey basin through the use of core samples from Lewumeji and Idogun well with depth ranging from $0-111 \mathrm{~m}$ and $0-54 \mathrm{~m}$ respectively. Detailed Information has been derived from the work, there by establishing the depositional environment, weathering condition, tectonic setting, transportation history, provenance and the classification of sediment from the well.

The wells were examined lithologically and five units were delineated which can be further grouped into three for Idogun well two units of shale, two units of sandstone and a clay unit while the lewumeji well has a lithology of sandstone and shale. Both well are dominated by fissile to blocky, light to dark grey colour shale and the sand grain varies from medium to fine grained texture showing dominance of quartz and the clay unit covers a small interval having a reddish brown colouration. This lithology denote Marine, fluvial and Lagoonal or brackish environment respectively

The bulk geochemical study of the sediments revealed that $\mathrm{SiO}_{2}$ is the dominant oxide followed by $\mathrm{Al}_{2} \mathrm{O}_{3}$, $\mathrm{Fe}_{2} \mathrm{O}_{3}$ and $\mathrm{CaO}$. The sediments in the study wells show relatively high value of $\mathrm{K}_{2} \mathrm{O} / \mathrm{Na}_{2} \mathrm{O}$ ratio indicating the presence of plagioclase. The relatively high $\mathrm{Fe}_{2} \mathrm{O}_{3}$ and $\mathrm{TiO}_{2}$ is an indication of iron-titanium minerals (haematite, anatase and rutiles) whereas very low value of $\mathrm{K}_{2} \mathrm{O} / \mathrm{Al}_{2} \mathrm{O}_{3}$ suggest sediment recycling or increase in the source area weathering. The weathering indices (CIA, CIW, and PIA) and the A-CN-K Ternary diagram indicate a sediment that has been subjected to high degree of weathering. The sediments are inferred as highly mature sediments evidenced from their high $\mathrm{SiO}_{2} / \mathrm{Al}_{2} \mathrm{O}_{3}$ ratio

The use of Herron's model classified the sediments as Fe- shale and Fe- sand. Also the AKF plots indicated 
that the sediments were gradually moving from the continental environment before been deposited shallow marine environment which is in agreement with the palynological deduction for paleoenvironment. This is an indication that the sediment has undergone moderate to high transportation under oxidising condition. the discriminant function plots of Roser and Korsch for the provenance signature studies reveals sediments dominants in mafic and quartzose sedimentary provenance with few inputs from intermediate igneous, as well as felsic igneous provenances. However, the bivariate plot of $\mathrm{TiO}_{2}$ versus $\mathrm{Zr}$ also indicates that most of the sediments from the wells are majorly from mafic source with minor from the intermediate and felsic source.

The Higher LREE/HREE and negative Eu anomalies from the chondrite normalization is an indication of a felsic source of the study area. The Ce anomalies and the values of $\mathrm{Ni} / \mathrm{Co}$ and $\mathrm{U} / \mathrm{Th}$ show that the redox condition during the sedimentation were oxic. Discriminant function diagram After Bhatia 1983 reveal the sediments are from passive margin this is also conforming to tectonic discriminant plots of Roser and Korsch, 1986. The use of Th-Sc-Zr/10 after (Bhatia and Crook, 1986) reveals that sediments of both wells plotted in the Continental Island Arc and Passive margins it therefore implies that the sediments were deposited in plate interiors or in an intracratonic basin.

\section{References}

1. Adeigbe, O.C. (2009): Geochemical characterisation of the Upper Cretaceous-Tertiary Clastic sediments in bornu Basin, Northeastern Nigeria. Unpublished PhD Thesis, University of Ibadan, Nigeria. 199p.

2. Adeigbe, O.C. and Jimoh, Y.A., (2013). Geochemical Fingerprints; Implication for provenance, Tectonic settings of Lower Benue Trough Sequence, Southeastern Nigeria. Journal of environment and earth science, ISSN 2224 -3216 (paper) ISSN (online). Vol 3, No 10, 2013s

3. Akpokodje, E. G., Etu-Efeotor, J. O., \& Olorunfemi, B. N. (1991). The composition and physical properties of some ceramic and pottery clays of South Eastern Nigeria. Journal of mining and Geology, 27, 9-15.

4. Bassey, C., and Eminue, O., (2014). Preliminary evaluation of major and trace elements content of Cretaceous- Palaeogene Formation of Sokoto Basin, Northwestern Nigeria. NAFTA 65(1) Pp 60 -76.

5. Besly, B.M., and Clearl, C.J. (1997). Upper Carboniferous Stratigraphy of the west Middlands (UK) raise in the light of Borehole geophysical logs and detrital compositional suites. Geology Journal, 32, 85-118

6. Bhatia, M. R., \& Crook, K. A. (1986). Trace element characteristics of graywackes and tectonic setting discrimination of sedimentary basins. Contributions to mineralogy and petrology, 92(2), 181-193.

7. Bhatia, M.R., (1983). Plate Tectonics and Geochemical Composition of Sandstones. Journal of Geology . V. 91, pp. $611-627$.

8. Biliman, H.G., (1992). Offshore Stratigraphy and Paleontology of the Dahomey (Benin) Embayment, West Africa. NAPE BULL., Vol. 7, No. 2 Pp. 121 -130.

9. Boboye, O.A., Adeyemi, M.S., and Madukwe, H.Y., (2018). Lithostratigraphy and Inorganic geochemical studies of Createceous- Tertiary Lithofacies from Nigerian Three Inland basin. Open journal of geology,8 , 711 -736. ISSN online : 2161 -7589

10. Burke, K. Dessauvagie, T.F.J and Whiteman, A.J. (1971). Geological history of the Benue valley and adjacent areas. In African Geology: Creatceous rocks of Nigeria and adjacent areas. University of Ibadan press, Ibadan, Nigeria. pp. 187-205, 1971.

11. Cingolani, C.A., Manassero, M. and Abre, P. (2003). Composition, provenance, and tectonic setting of Ordovician siliciclastic rocks in the San Rafael block: Southern extension of the Precordillera crustal fragment, Argentina: Journal of South American Earth Sciences, 16(1): 91-106.

12. Cullers, R. L., Yeh, L. T., Chaudhuri, S., \& Guidotti, C. V. (1974). Rare earth elements in Silurian pelitic schists from NW Maine. Geochimica et Cosmochimica Acta, 38(3), 389-400.

13. Cullers, R.L., (1995). The controls on the major and trace element evolution of shales, siltstone and sandstone of Ordovician to Tertiary age in the Wet Mountains region, Colorado,USA. Chemical Geology 123: 107-131.

14. Dabard, M. P. (1990). Lower Broverian Formations (Upper Proterozoic) of the Armorican Maesit (France): Geodynamic evolution of source areas revealed by sandstone petrography and geochemistry. Sedimentary Geology, 69, 45-58.

15. Dill, H. (1986). Metallogenesis of early Paleozoic graptolite shales from the Graefenthal Horst (northern Bavaria-Federal Republic of Germany). Economic Geology, 81(4), 889-903.

16. Dypvik, H. (1984). Jurassic and Cretaceous black shales of the Janusfjellet formation, Svalbard, Norway. Sedimentary Geology, 41(2-4), 235-248.

17. Englund, J.O., \& Jorgensen, P., (1973). A chemical classification system for argillaceous sediments and factors affecting their composition Geol. Stockholm Forh. 95, 87-97.

18. Fedo, C.M., Nesbitt, H. W. \& Young, G. M. (1995). Unraveling the effects of potassium metasomatism in sedimentary rocks and paleosols, with implications for paleoweathering conditions and provenance. Geology, 23: 10, p.921- 924 .

19. Goldberg, K. and Munir Humayun, M., (2010). The applicability of the Chemical Index of Alteration as a 
paleoclimatic indicator: An example from the Permian of the Paraná Basin, Brazil. Palaeogeography, Palaeoclimatology, Palaeoecology, 293, 175- 183.

20. Harnois, L., (1988). The new index, a new chemical index of weathering. Sedimentary Geology V. 55, pp 319- 322.

21. Hayashi, K., Fujisawa, H., Holland, H., Ohmoto, H. (1997). Geochemistry of $\sim 1.9$ Ga sedimentary rocks from northeastern Labrador, Canada. Geochimica et Cosmochimica Acta , 61(19), p. 4115-4137.

22. Herron, M.M., (1988). Geochemical Classification of Terrigenous Sands and Shales from core to log data. Journal of sedimentary Petrology , V. 58, pp. 820 - 829

23. Jenner, G. A., Fryer, B. J., \& McLennan, S. M. (1981). Geochemistry of the Archean Yellowknife Supergroup. Geochimica et Cosmochimica Acta, 45(7), 1111-1129.

24. Jones, B. and Manning, D.A.C. (1994). Comparison of Geochemical Indices Used for the Interpretation of Palaeoredox Conditions in Ancient Mudstones. Chemical Geology, 111, 111-129.

25. Kalsbeek, F., Frei, D., Affaton, P., (2008). Constraints on Provenance, Stratigraphic Correlation and Structural Con-text of the Volta Basin, Ghana, from Detrital Zircon Geo-chronology:An Amazonian Connection? J. Sedimentary Geol. 212:86-95.

26. Kingston, D.R., Dishroon, C.P and Williams, P.A., (1983). Global Basin classification system. American. Assoc. of petroleum Geologists .Bulletin. Vol.67, Pp 2175 -219331,

27. Kirschbaum, A., Martinez, E., Pettinari, G. and Herrero, S., (2005). Weathering profiles in granites, Sierra Notre (Cordoba, Argentina).Journal of South American Earth Sciences, 19, 479-493.

28. Klemme, H.D., (1975). Geothermal Gradients, Heatflow and hydrocarbon Recovery, In; A.G. Fischer and S. Judson (eds), petroleum and Global tectonics, Princeton, New Jersery, Princeton Univ. Press, Pp. 251 - 304.

29. Le Maitre, R.W., (1976). The chemical variability of some common igneous rocks. J. Petrol., 17: 589-637.

30. Lewis Jr, R. W., and Bandeira, C. S. (1981). The use of petroleum-well samples and data for geochemical prospecting of metals in sedimentary basins. In Developments in Economic Geology (Vol. 15, pp. 251-260). Elsevier.

31. Madukwe, H.Y., Ayodele, S.O., Akinyemi, S.A. and Adebayo, O.F (2016). Classification, Maturity, provenance, Tectonic setting, and source- Area weathering of Ipole and Erin Ijesa Sedeiments, South west Nigeria. International journal of advanced scientific and Technical Reasearch. Issue 6.vol.1, ISSN 2249 9954.

32. Maynard, J.B., Valloni, R., Yu, H.S., (1982). Composition of modern deep-sea sands from arc-related basins. In: Leggett, J.K. (Ed.), Trench and Fore-arc Sedimentation. The Geological Society of London, pp. 551-561 (Special Publications 10)

33. McDaniel, D.K., Hemming, S. R., Mclennan, S.M. and Hanson, G.N. (1994). Resetting of neodymium isotopes and redistribution of REE'S during sedimentary processes: The early Proterozoic Chelmsford formation,

34. Mclennan, S. M., Taylor, S. R., McCulloch, M. T., \& Maynard, J. B. (1990). Geochemical and Nd-sr isotopic composition of deep sea turbidities: Crustal evolution and plate tectonic association. Geohimica et Cosmochimica Acta, 54, 2015-2050. http://dx.doi.org/10.1016/0016-7037(90)90269-Q

35. McLennan, S.M., Hemming, S., McDaniel, D.K., and Hanson, G.N., (1993). Geochemical Approaches to Sedimentation, Provenance and Tectonics. In: Processes Controlling the Composition of Clastic Sediments, Johnson, M.J. and A. Basu (Eds.). Geological Society of Amercain Special Paper, USA., pp: 21-40.

36. Milodowski, A.E. and Zalasiewkz, J.A. (1991). Redistribution of rare earth elements during diagenesis of eurbidice /hemipelagic mudrock sequences llandovery age from central Wales. In: AC. Mortan, S.P. Todd and P. D.W. Houghton (Editors), Geological Society London Special Publications, 57, 101-124.

37. Nagarajan, R., Madhavaraju, J., Nagendra1, R., Armstrong-Altrin, J. S., and Moutte, J. (2007). Geochemistry of Neoproterozoic shales of the Rabanpalli Formation, Bhima Basin, Northern Karnataka, southern India: implications for provenance and paleoredox conditions. Revista Mexicana de Ciencias Geológicas , v. 24, núm. 2, p.150-160.

38. Nath, B. N, Kunzendorf H, Pluger W.L., (2000). Influence of provenance, weathering and sedimentary processes on the elemental ratio of the fine-grained fraction of the bed load sediments from the Vembanad Lake and the adjoining continental shelf, southwest Coast of India, J. Sedimentary Res. 70:1081- 1094.

39. Nesbitt, H.W., Young, G. M. (1982). Early Proterozoic climates and plate motions inferred from major element chemistry of lutites. Nature, V. 299, p.715-717.

40. Nton, M.E. and Elueze, A.A. (2005). Composition Characteristics and Industrial Assessment of Sedimentary Clay bodies in part of Eastern Dahomey basin, Southwestern Nigeria. J. Min. And Geol. Vol.4 (12) Pp 175184.

41. Ogbahon, O. A., \& Olujinmi, O. B. (2019). Geochemistry of Maastrichtian Clastic Sedimentary Rocks from Western Flank of Anambra Basin, Nigeria: Implications for Provenance,Tectonic Setting, Paleoclimate and Depositional Paleoenvironment. International Journal of Geosciences, 10, 91-118. 
42. Osae, S., Asiedu, D.K, Banoeng-Yakubo B, Koeberl, C., Dampare, S.B., (2006). Provenance and tectonic setting of Late Proterozoic Buem sandstones of southeastern Ghana: Evidence from geochemistry and detrital modes, J. Afr. Earth Sci. 44:85- 96.

43. Paikaray S., Banerjee S., and Mukherji S. (2008). Geochemistry of shales from to Neoprotzoic Vindhyan Super-group: Implications on provenance, tectonic and paleoweathering. Journal of Asia Earth Science. 32, 34-48.

44. Pearse, I.J., Bersly, B.M., Wiray, D.S. and Wright D.K (1999). Chemostratigraphy: a model to improve interwell correlation in barren sequence. " a case study using offshore Duekmantian/ stephanian sequence" (West Midlands, UK). Sedimentary Geology (124), Pp. 127 -200.

45. Pettijohn, F. J., (1963). Sedimentary Rocks, 2 nd edn, Harper and Row, New York. 628pp.

46. Pettijohn, F. J., Potter, P. E., and Siever, R., (1972). Sand and sandstone: New York, Springer, 618 p.

47. Piper D.Z., (1974). Rare earth elements in the sedimentary cycle: A summary. Chemical Geology, V14, pp 285-304.

48. Popoola, S.O., Appia, Y.J. and Oyatola, O.O., (2014). The depositional environments and provenance characteristics of selected sediments, South Yewa River, Eastern Dahomey Basin, Southwestern Nigeria. Journal of applied geology and geophysics. Vol. 2, Issue 5, Pp $98-121$

49. Rimmer, S.M. (2004). Geochemical Paleoredox Indicators in Devonian-Mississippian Black Shales, Central Appalachian Basin (USA). Chemical Geology, 206, 373-391.

50. Roser, B. P. and Korsch, R. J. (1988). Determination of the tectonic setting of sandstone-mudstone suites using $\mathrm{SiO} 2$ content and $\mathrm{K}_{2} \mathrm{O} / \mathrm{Na}_{2} \mathrm{O}$ ratio Journal of Geology 94, 635-650.

51. Roser, B.P., \& Korsch, R.J., (1986). Determination of tectonic setting of sandstone. Mudstone suites using $\mathrm{SiO}_{2}$ content and $\mathrm{K}_{2} \mathrm{O} / \mathrm{Na}_{2} \mathrm{O}$ ratio: Journal of Geology, V. 94, pp $635-650$.

52. Roser, B.P., Cooper, R.A., Nathan, S. and Tulloch, A.J. (1996). Reconnaissance sandstone geochemistry, provenance, and tectonic setting of the lower Paleozoic terraines of the West Coast and Nelson, New Zealand. New Zealand J. Geol. Geophys, 39: 1-16.

53. Sethi, P.S., Hannigan, R. E., Leithold, E.L., (1998). Rare-earth element chemistry of Cenomanian- Turonian shales in the North American Greenhorn Sea, Utah. In: Schieber J, Zimmerle W, Sethi P (eds) Shales and Mudstones II. E. Schweizerbart'sche Verlagbuchhandlung (Nägele u. Obermiller), Stuttgart, pp 195-208.

54. Sun, S.S. and McDonough, W.F. (1989). Chemical and isotopic systematics of oceanic basalts implications for mantle composition and processes. In: Saunders AD, Norry MJ (eds) Magmatism in the Ocean Basins. Geological Society of London, Special Publication 42, London, pp 313-334

55. Taylor, S.R., and McLennan, S.M. (1985). The Continental Crust: Its Composition and Evolution. Blackwell, Oxford, UK., ISBN-13: 978-0632011483, Pages: 312

56. Whiteman, A.J., (1982). Nigeria, its petroleum Geology of Nigeria, resources and potential, Vol 2 Pp $223-$ 230 Graham and Trotman, London.

57. Zhang, K.L., (2004). Secular geochemical variations of the Lower Cretaceous silica from central Tibet (China) indicate a tectonic transition from continental collision to back-arc rifting, Earth and Planetary Science Letters, 229:73- 89. 